NBER WORKING PAPER SERIES

WHY DID COUNTRIES ADOPT THE GOLD STANDARD? LESSONS FROM JAPAN

\author{
Kris James Mitchener \\ Masato Shizume \\ Marc D. Weidenmier \\ Working Paper 15195 \\ http://www.nber.org/papers/w15195
NATIONAL BUREAU OF ECONOMIC RESEARCH
1050 Massachusetts Avenue
Cambridge, MA 02138 \\ July 2009
}

\begin{abstract}
We thank Simon Bytheway, Steve Quinn, Hisahiko Saito, and Michael Schlitz as well as seminar participants at Rutgers University, Kobe University, IFN, Warwick University, the Solvay Business School at Universite Libre de Bruxelles, and the Bank of Japan for comments and suggestions. We also thank Genna Tan, Ronald Choi, and Lydia Fung for excellent research assistance. The National Science Foundation (NSF Grant 0518661) provided financial support for this project. Mitchener also thanks the International Institute, UCLA, for financial support while working on this project as a Global Fellow in 2008-9. The views expressed herein are those of the author(s) and do not necessarily reflect the views of the National Bureau of Economic Research.
\end{abstract}

NBER working papers are circulated for discussion and comment purposes. They have not been peerreviewed or been subject to the review by the NBER Board of Directors that accompanies official NBER publications.

(C) 2009 by Kris James Mitchener, Masato Shizume, and Marc D. Weidenmier. All rights reserved. Short sections of text, not to exceed two paragraphs, may be quoted without explicit permission provided that full credit, including $(\odot)$ notice, is given to the source. 
Why did Countries Adopt the Gold Standard? Lessons from Japan

Kris James Mitchener, Masato Shizume, and Marc D. Weidenmier

NBER Working Paper No. 15195

July 2009

JEL No. E58,F33,N15,N25,N75

\begin{abstract}
Why did policymakers adopt the gold standard? Although previous research has identified ex post effects of gold standard adoption on trade and bond yields, few studies have sought to understand whether these were the actual outcomes of interest to policymakers at the time of adoption. We examine the political economy of Japan's adoption of the gold standard in 1897 by exploring the ex ante motives of policymakers as well as how the legislative decision to adopt gold won approval. We then link the beliefs of contemporaneous policymakers to data so that we can test the economic effects of adoption. In contrast to previous studies examining bond yields, we find little evidence that joining the gold standard reduced Japan's country risk or investors anticipated a dramatic decline in borrowing rates for the government. Moreover, we find no evidence of a domestic investment boom or that investors anticipated one and bid it into stock prices. However, as some policymakers suggested, we find that membership in the gold standard increased Japan's exports by lowering transactions costs and because the price of gold fell relative to silver, making exports to silver standard countries more competitive. While Japan also received a boost in exports to its regional trading partners when it switched from paper to silver, going onto gold allowed Japan to tap into the growing share of global trade that was centered on the gold standard: by the late 1890s nearly 60 percent of Japanese exports and total trade were with members of the gold club.
\end{abstract}

Kris James Mitchener

Department of Economics

Leavey School of Business

Santa Clara University

Santa Clara, CA 95053

and NBER

kmitchener@scu.edu

Masato Shizume

Institute for Monetary and Economic Studies

Bank of Japan

Nihonbashi-Hongokucho, 2-1-1, Chuo-ku

Tokyo, Japan

PXS00714@nifty.ne.jp
Marc D. Weidenmier

Robert Day School of Economics and Finance

Claremont McKenna College

500 East Ninth Street

Claremont, CA 91711

and NBER

marc_weidenmier@claremontmckenna.edu 


\section{Why did Countries Adopt the Gold Standard? Lessons from Japan}

Why did countries join the gold standard? Recent research in economic history has generally focused on two explanations. Bordo and Rockoff (1996) argue that adherence to the monetary rule was "a good housekeeping seal of approval," which signaled to international capital markets that countries were committed to pursuing prudent monetary and fiscal policies. ${ }^{1}$ Investors rewarded countries that joined the gold standard by lowering their cost of capital in financial markets by approximately 30 basis points (Obstfeld and Taylor, 2003). Another explanation for joining the gold standard focuses on the importance of fixed exchange rates in facilitating international trade. Flandreau and Maurel (2005) and LopezCordova and Meissner (2003) provide evidence that the gold standard increased bilateral trade flows between 50 and 100 percent during the period 1870-1913. These studies argue that the hard peg promoted international trade perhaps by reducing transaction costs or exchange-rate volatility. ${ }^{2}$

Although these studies correlate economic outcomes with the adoption of a hard peg, they provide little insight into the choice decision itself and whether contemporaries believed gold standard adoption would affect trade and borrowing costs. ${ }^{3}$ To understand why countries would willingly choose to tie the hands of their monetary authorities and join the gold standard, it is necessary to examine the policy debates at the time of adoption and the factors that led to adoption. Then, one can test whether adoption had intended effect or unintended consequences.

While such an analysis might be theoretically possible at a cross-country level, it is likely to be more feasible to collect detailed information on the policy process and multiple outcome variables for a single country. In this paper, we suggest that Japan's adoption of the gold standard in 1897 provides a

\footnotetext{
${ }^{1}$ Flandreau and Zumer (2005) and Ferguson and Schularick (2006a, 2006b) provide evidence that the gold standard did not reduce the cost of capital during the gold standard period using a large sample of countries along with additional control variables in their regressions.

${ }^{2}$ The precise mechanism is not specified.

${ }^{3}$ An exception is Meissner (2005), which considers multiple factors that affected a country's decision about when to adopt the gold standard. However, the analysis is primarily concerned with the process of gold standard diffusion rather than the political economy of adoption, and does not explicitly consider why countries adopted and how the decision to adopt then impacted economic outcomes such as borrowing cost, investment, and trade flows.
} 
well-suited laboratory for understanding why countries adopted hard pegs and how such a decision affected their economies. Japan's experience is particularly interesting for three reasons. First, late nineteenth-century Japan has many of the characteristics of today's emerging market economies: it was a small open economy with an expanding trade sector and a desire to borrow in international capital markets. Examining Japan's experience may help us better understand the decision making of countries that adopt hard pegs today. Second, Japan's historical archives provide detailed information on the political economy of gold standard adoption and the role of special interest groups in the decision making process. Furthermore, primary source materials from the nineteenth century also permit us to collect high frequency price and yield data on domestic stocks and bonds as well as annual data on bilateral trade flows that can be used to test ex ante and ex post economic effects of gold standard adoption. Third, previous researchers have argued that Japan represents the canonical case of an emerging market borrower benefiting from lower borrowing costs after adoption of a hard peg (Sussman and Yafeh 2000, 2006). We examine whether policymakers viewed this as a central objective of gold standard adoption, and using a more complete database of Japanese sovereign debt and domestic debt issues, we re-assess whether borrowing rates actually fell after adoption.

Evidence from the legislative debates of the 1890s suggests that policymakers believed gold standard adoption could impact borrowing costs, debt issuance, domestic investment and trade. ${ }^{4}$ We show that, despite staunch opposition from the business community, the ruling party government was able to engineer passage of the gold standard act of 1897 by gaining the legislative support of a key opposition party during committee deliberations. Without the support of the Progressives, Prime Minister Masayoshi Matsukata would not have been able to carry the vote.

Using newly-assembled data on trade flows and asset prices, we explicitly link the legislative debates to the beliefs of contemporaneous investors and to realized economic outcomes. Although some participants in the parliamentary debates suggested that Japan would benefit from lower rates of borrowing, we find no discernable trend in bond prices that would indicate that investors anticipated

\footnotetext{
${ }^{4}$ Contemporary economists also noted there was debate over gold standard adoption. See Laughlin (1897).
} 
lower rates of borrowing. Furthermore, after it adopted the gold standard, Japan's realized rates of borrowing in both international and domestic capital markets did not fall. Likewise, we find no evidence of domestic investors' bidding up stock prices in anticipation of an investment boom, nor do we observe a boom in domestic investment in the wake of adopting the gold standard.

Japanese policymakers of the nineteenth century also suggested that going onto gold would affect trade, but they were decidedly mixed as to whether it would increase it or reduce it. In examining the ex post effects of adoption, we find that both the opponents of adopting the gold standard (like the business community which had argued that Japan was receiving large benefits from being on silver) as well as proponents (like the ruling party, which had argued Japan would benefit from lower transactions costs and exchange rate volatility) turned out to be correct. Estimates from a gravity model of Japanese exports suggest that Japan received a large boost in trade when Japan and its partners were on the silver standard. However, gold standard adoption also significantly boosted exports and trade. It did so in two ways. First, Japan adopted the currency system through which most of the world's trade was being conducted by the end of the nineteenth century. By joining the gold standard, it lowered transactions costs and exchange rate volatility vis-à-vis other gold standard countries. The fact that it abandoned its regional and historically relevant, silver-standard trading partners for the gold standard conducted, enabled it to plug into the monetary system through which most of the world's trade was being conducted by the end of the nineteenth century. By 1897, approximately 60 percent of Japanese exports and total trade were with countries that were on the gold standard (or countries taking measures to join the gold club within a couple of years). Second, Japan's fortuitous timing of gold standard adoption proved beneficial for some of its exports. In particular, Japanese exports to silver standard countries received an additional boost in competitiveness because Japan adopted the gold standard right as silver began to appreciate against gold.

The next section of the paper discusses the events leading up to Japan's decision to go on the gold standard, the debates among Japanese policymakers over the adoption of the gold standard, and the factors which led to legislative passage of the gold standard act in 1897. Section III examines evidence from bond markets in both London and Tokyo to analyze the impact of gold-standard adoption on 
sovereign yield spreads. Section IV employs a gravity model to assess the impact of adopting the gold standard on bilateral trade flows. Section V assesses whether investors bid up bond prices in anticipation of a domestic investment boom in Japan and whether Japan then subsequently realized a boom after gold standard adoption. Section VI discusses the implications of our results for hard pegs and for the financial history of the Meiji period.

\section{The Decision to Adopt Gold}

During the Meiji period, Japan parted ways with its feudal past and began to forge a new national identity for its economy. It turned outward in its orientation (initially induced by the "gunboat diplomacy" of Western powers), developing industries and trading companies that sold products such as silk in overseas markets and borrowing internationally to fund internal improvements that would facilitate the movement of goods and people. ${ }^{5}$

At the same time Japan was forging a national economy, it was experimenting with institutions that would foster economic growth and stability. It introduced a national currency, the yen, in 1871. It imported the U.S. model of a national banking system in 1872, and in 1876, allowed these national banks to issue paper notes backed by government bonds. These early monetary institutions resulted in unsustainably high inflation rates in the late 1870 s and early 1880 s, and paved the way for the Japanese government to centralize control over the money supply. The Bank of Japan was founded in 1882, and thereafter, it began issuing convertible notes that hastened the demise of commercial bank note issuance. Japan adopted the silver standard in May 1885 and had made all yen-denominated paper money issued by the government convertible to silver by January 1886. It stayed on the silver standard for eleven years.

Beginning in 1893, the government made preparations to join the gold standard. The veteran finance minister, Count Masayoshi Matsukata, initiated the program ${ }^{6}$. The government formed the

\footnotetext{
${ }^{5}$ Its first national debt, issued in London in 1870 financed railway construction.

${ }^{6}$ Matsukata played a central role in implementing the monetary and financial reforms of the Meiji era. As an official of Ministry of Finance, he helped to engineer the fiscal stabilization program of the 1870s. As Finance Minister, he also initiated the movement to establish the central bank, the Bank of Japan.
} 
Committee on the Monetary System to explore what monetary system would be best for Japan's economy in the long run. The committee was charged with determining the global causes of gold-silver price fluctuations and their consequences on the Japanese economy, and with recommending the monetary standard that would be best suited for Japan. As finance minister, Kunitake Watanabe, stated in setting up the committee, "Fluctuations in the price of gold and silver are having significant effects on the Japanese economy and fiscal conditions. I propose to set the committee on the monetary system....and the government will refer to it for building its strategy on monetary matters."

After seven general meetings and 41 task force meetings, the committee submitted its final report to the returning and reappointed finance minister Matsukata, on July 3, 1895. Only one of the seven task force members, a protégé of Matsukata, insisted on an immediate move to the gold standard. Of the 15 members on the main committee (composed of government officials, business leaders, and academics), seven wanted to retain silver, six suggested moving to gold at some point in the future, and two desired a bimetallic standard. Most of the supporters of gold standard adoption were bureaucrats and politicians with close relationships to Matsukata whereas opponents were largely business leaders and academics. Despite the tepid response of the committee, Matsukata continued to press for monetary reform, and was emboldened to do so once China was forced to pay a large indemnity to Japan at the conclusion of the Sino-Japanese War in 1895. Matsukata's strategy was to request that China pay the indemnity in poundsterling in London even though the original treaty stated it would be paid in silver taels. The pound sterling would then enable Japan to acquire gold reserves so that it could move onto the gold standard.

After two years' preparation for introducing the gold standard, including acquisition of gold reserves in overseas markets, in March of 1897, the ruling government (led by Matsukata, who had been both Prime Minister and Finance Minister since September 1896) officially submitted legislation to the Imperial Diet authorizing a gold standard.

Once the bill was introduced, fierce debate erupted in the legislative branch of the Japanese government. Although a relatively new political institution, the Japanese Imperial Diet of the 1890s served as a counterweight to the Prime Minister-led positions of the Emperor's ruling government 
(Muramatsu, Ito, and Tsujinaka, 2001, p.82). ${ }^{7}$ During the 1890 s, the Diet routinely rejected and cut the budget prepared by the ruling government, including military projects, hence exercising its right to provide a check on the national budget. ${ }^{8}$ In contrast, the military was not a major political player until at least the end of the Russo-Japanese War (1904-5). ${ }^{9}$

Without the support of at least some factions of the two major opposition parties (the Progressives and the Liberals), the ruling government stood little chance of passing any legislation, including authorization to establish the gold standard in the 1890s. For example, in September 1896, when Matsukata formed the Cabinet, with which he eventually introduced the gold standard, there were 111 Liberals, 99 Progressives, and at most 89 out of the 300 seats (one vacant) of the House of Representatives (lower house of the Diet) who could be counted as supporting the ruling government (Table 1).

National legislators such as Atsushi Kawashima, a member of Giin Kurabu [Assembly Members' Club], a political faction that supported the ruling government backed Matsukata's position, and made spirited arguments in favor of adoption. ${ }^{10}$ For example, Kawashima argued that "financial credibility

\footnotetext{
${ }^{7}$ Right after the Meiji Restration (1868), Japanese government was led by ex-samurai from Kagoshima (called exSatsuma) and Yamaguchi (called ex-Choshu). The move to establish representation and form a Diet (the liberal democratic rights movement) surged in the 1870s and 1880s against the dominance of ex-Satsuma and ex-Choshu in political scene. Prior to the establishment of the first national Diet in 1890, an electoral system was introduced at the prefectural level in 1879. A myriad of political parties was formed during the 1880 s, including the powerful Liberal (Jiyu-to) and Progressive (Kaishin-to) parties. (Kaishin-to was sometimes also referred to by English contemporaries as the "Progressists" or "Progressionists" party. In 1896, Kaishin-to merged with other four smaller parties and renamed Shinpo-to.) The first session of the Diet occurred in November 1890. Prime Ministers were appointed by the Emperor with the consultation from Senators (Genro), or veterans of Meiji Restoration of 1868, most of whom were ex-Satsuma or ex-Choshu. Higher-ranking government bureaucrats were also dominated by exSatsuma and ex-Choshu.

${ }^{8}$ The independent actions of the Diet in the 1890 s represented a major change from the doctrine of responsibility to the emperor alone. Regarding the challenge to the government that came from the Diet, the press reported that "political parties stoutly asserted the principle of administrative responsibility to the Diet, and employed, with wholesale zeal, the only available means of enforcing their views - namely, destructive opposition in the Legislature...the public did not fail to interpret the change correctly." ("Japanese Politics, "The Times (London), December 4, 1896, p.8.)

${ }^{9}$ Harada (2007), pp.34-42.

${ }^{10}$ Atsushi Kawashima (1847-1911) was a member of House of Representatives. His career demonstrates close ties with Matsukata. He was born in Kagoshima, the same prefecture as Matsukata. He had served in the Ministry of Finance before being elected from his home region in the first national election in 1890 . He was a member of the previous Committee on the Monetary System, and he supported the gold standard upon the voting on the committee's final report. During the debate in the Diet in 1897, he belonged to a political fraction named Assembly Members' Club (Giin Kurabu), which supported the ruling government. In June 1897, two months after the passage
} 
would be improved." He opined that it would not only enhance Japan's military power and domestic economy, but it would also stabilize Japanese finances. Japan's yen-based payments would not be subject to exchange-rate risk. Kawashima suggested that adopting gold would enhance foreign investors' credit on Japanese government debts and help Japan attract foreign capital at reduced rates. He argued cheap and affluent foreign capital could be used to build up a stronger military and promote domestic business activities. $^{11}$

Legislative proponents also argued that going on gold would enhance trade. For example, Kawashima commented that "to compete with other countries in the trade sphere, we must have the common world currency as others do... The gold standard is beneficial for the development of commerce and industries. Japan's main trading partners are the gold-standard countries." ${ }^{12}$ Ministry of Finance officials had drawn similar conclusions in the 1895 report, arguing that "many of the once-famous silver standard countries such as Mexico...have already moved to the gold standard. These trends indicate the natural course for Japan in financial and economic spheres" (Sakatani, Appendix to Final Report of the Committee). ${ }^{13}$

In addition to the benefits arising from what are now referred to as network externalities, Kawashima suggested that gold standard adoption would reduce exchange-rate volatility and currency risk. "Japan has suffered from fluctuations in domestic prices induced by exchange rate fluctuations. The price fluctuations induced by exchange rate fluctuations will disappear under the gold standard. Foreign banks have gotten a substantial premium on foreign exchange transactions of Japanese companies. The Japanese companies do not have to pay such premium once we introduce the gold standard. Foreign buyers of Japanese products will request the products more if the prices of the products are stable under

of the bills introducing the gold standard, he resigned to become the first Governor of Japan Hypothec Bank (Nippon Kangyo Ginko), which was also established under Matsukata's leadership.

${ }^{11}$ Imperial Diet (1897), reprinted in Bank of Japan (1960, pp.133-134). Other policymakers, however, suggested this was unnecessary as Japan could simply issue debt denominated in gold.

${ }_{12}^{12}$ Imperial Diet (1897\} reprinted in Bank of Japan (1960, p.135).

${ }^{13}$ Committee on the Monetary System (1895) reprinted in Bank of Japan (1957, p.901). 
the gold standard." ${ }^{14}$ Similarly, Juichi Soeda, Counselor of the Ministry of Finance, concluded: "Unless we could remove the exchange rate risk, we could not expect proper development of Japanese foreign trade." 15

Proponents of the gold standard suggested that adoption might also lead to an investment boom: "If we introduce the gold standard, foreign capital will invest in the Japanese markets and buy Japanese government bonds and private securities, and the Japanese commerce and industries will be booming." 16

In introducing the authorizing legislation, Matsukata summed up the Cabinet's position: "First, fluctuations of prices will be smaller under the gold standard than under the silver standard. Second, the introduction of the gold standard will promote trade, especially with other gold standard countries. Third, the introduction of the gold standard will reduce exchange rate risk with gold standard currencies. Fourth, the gold standard will connect the Japanese financial market to overseas markets. As our country has been developing, we need more communication with overseas financial markets. Fifth, the introduction of the gold standard will benefit public finance."17

Before becoming law, the legislation would have to first clear a vote at the committee level and then before the entire Diet. While the proponents of going onto the gold standard had the powerful backing of Matsukata and the Ministry of Finance, many other legislators believed that adopting the gold standard would hurt the Japanese economy and that the timing was not propitious. They noted that the majority opinion of the 1895 report had concluded that recent fluctuations in the gold-silver price (while Japan was on the silver standard) had increased the volume of exports, reduced the burdens of debtors and fixed taxpayers, created a boom in agriculture, and led to prosperity in commerce and industry. As Eiichi Shibusawa, one member of the 1895 committee and a prominent business leader wrote: "The exports to

\footnotetext{
${ }^{14}$ Imperial Diet (1897) reprinted in Bank of Japan (1960, p.135).

${ }^{15}$ Imperial Diet (1897) reprinted in Bank of Japan (1960, p.158).

${ }^{16}$ Comments of Atsushi Kawashima. Imperial Diet (1897), reprinted in Bank of Japan (1960, p.136).

${ }^{17}$ Speech of Finance Minister Court Masayoshi Matsukata. Ministry of Finance (1905, pp.182-183). Matsukata suggested that the way the gold standard would increase exports was by reducing price fluctuations and making commercial transactions more convenient (Matsukata's speech cited in "The Gold Standard," The Oregonian, August 7, 1897). Matsukata may have also believed that adopting gold would increase the prestige and standing of Japan internationally, and that it was broadly consistent with the national goals of modernizing Japan's economy and military.
} 
gold standard countries increased by more than 260 percent from 1878 to 1893 while the imports from these countries only increased by 70 percent over the same period. This is because the price of exports has fallen while the price of imports has risen. This has promoted the development of industries, technical progress, and growth in the demand for labor. These benefits exceed the costs of being a silver standard country." (Shibusawa, Appendix to Final Report of 1985). ${ }^{18}$

In the late $19^{\text {th }}$ century, Emperor Meiji set national goals of "bringing more wealth to the nation, and building a stronger military (fukoku kyouhei)." Business leaders such as Eiichi Shibusawa argued that staying on silver would be consistent with those goals. Shibusawa wrote, "The effects of the recent fluctuation in parity of gold and silver are quite beneficial to our economy in general under the current monetary system. Japanese exports to gold standard countries have increased more than imports from them. This is because the price of exported goods falls, while the price of imported goods increases. This has promoted development of industries, import substitution of many products, technical progress, growth in the demand for labor, and expanded national wealth. These benefits exceed the costs of being a silver standard country. If Japan introduces the gold standard, prices would fall, and business conditions would deteriorate, affecting the economy and society badly.” (Shibusawa, Appendix to Final Report).

The business community was also largely in favor of remaining on the silver standard as exportproducing sectors of the economy had benefited from the depreciation of silver. ${ }^{19}$ In 1898 , economist Garrett Droppers wrote in the Quarterly Journal of Economics the following about the business community's view on Japan's monetary standard: “From 1886 to 1897, a period of over a decade, it is doubtful whether there was the slightest demand for return to the gold standard. On the contrary, every

\footnotetext{
${ }^{18}$ Eiichi Shibusawa (1840-1931) was born into a family that was involved in sericulture located near Tokyo. After the Meiji Restoration, he joined Ministry of Finance and drafted the legislation to introduce a single unit of currency, the yen, and to establish the National Banking system. When he left the government in 1873 he established and/or run a number of Japan's leading companies, including First National Bank, Oji Paper, Osaka Spinning, Kanegafuchi Spinning, Tokio Marine Insurance, Nippon Yusen (NYK Line), Japan Railway, and the Tokyo Stock Exchange. He chaired Tokyo Chamber of Commerce from 1878 to 1905 and often represented the viewpoints of the business community in national political debates. In Japan, he has been referred to as "Father of Japanese Capitalism."

${ }^{19}$ Contemporaries from other countries also expressed doubt about the beneficial effects of the gold standard that the Japanese government was touting: "Foreigners, and even foreign political economists, in this country are nearly all trying to dissuade Japan from making the change, clearly pointing out the disadvantages to trade and industries that would accrue from the adoption of the gold standard." "The Gold Standard in Japan," The Economist, April 24, 1897, p.603.)
} 
so-called decline of silver was hailed with general satisfaction by those engaged in industrial and commercial pursuits. ${ }^{20}$

Opposition from the business community to the gold standard was, in part, a function of the more unified voice of exporters. Based on data from the 1890s, Japan's exports were concentrated in a few key commodities and industries. Forty-one percent of Japanese exports were silk products, and 27 percent were tea, rice, and matches. ${ }^{21}$ The value added of these commodities was almost entirely domestic, and Japanese producers of these goods had gained the most from the depreciation of the silver yen against gold-standard currencies. In contrast to exports, there was no single import that accounted for a large portion of total imports. Raw cotton accounted for 19 percent, sugar for 10 percent, machinery for 9 percent, and petroleum for 4 percent. Given that imports were used as inputs into a variety of products or were final goods sold to consumers, it proved more difficult for policymakers to drum up support from the business community to jettison the silver standard, since no one industry was experiencing a disproportionate rise in input prices (due to the depreciation of silver).

Politicians opposing the gold standard sided with the business community and many members of the Committee on the Monetary System in arguing against adoption. Kungoro Shigeoka of the opposition Liberal Party argued that Japan's export industries would be hurt since the price of silver had been declining relative to gold while Japan was on the silver standard. He reasoned that the increase in exports outweighed the costs of exchange-rate volatility: "Although fluctuations in gold-silver exchange rates might induce some inconvenience for foreign trade, the advantages in competitiveness for the silver standard surpass the inconvenience effect." ${ }^{22}$ Shigeoka also maintained that adoption of gold would commit Japan to persistent trade deficits driven by cheap imports and expensive exports (due to gold's appreciation relative to silver). Ironically, it was the export boom during the silver standard that may have

\footnotetext{
${ }^{20}$ Droppers (1898, p.164)

${ }^{21}$ Figures are average shares of exports based on data from 1893-1897.

${ }^{22}$ The great Meiji era entrepreneur Shibusawa Eiichi also argued that Japanese businesses had benefited immensely from cheaper exports during the silver standard; he became the flag bearer of the business community's opposition to gold standard adoption (Metzler, 2006, p.30). In contrast, the Ministry of Finance argued that the benefits to trade and industry were only temporary.
} 
enabled Japan to go onto the gold standard. According to Miller (2007), export revenues during the period of silver deflation enabled the Imperial Navy of Japan to purchase British cruisers, defeat China in the Sino-Japanese War of 1894-5, and acquire the indemnity payable in gold, which enabled Japan to go onto the gold standard.

In addition, Shigeoka argued the time was not right because Japan had no tariff autonomy. The so-called "unequal treaties" it was forced to sign with European powers and the U.S. in the 1860s limited its ability to set tariff rates on imports. He also argued that, even if going on gold would allow Japan to borrow at lower rates, these rates would only be temporary: the fall in exports to gold countries (due to leaving silver) would cause foreign investors to lower their assessment of Japan's growth rate and, in the end, result in Japan having to borrow at higher rates. ${ }^{23}$

Despite this opposition, Matsukata and his allies prevailed by forging a strategic alliance with a key opposition party, the Progressive Party (Shinpo-to). In particular, when Matsukata formed the cabinet in September 1896, and as a condition of his acceptance of the post of Prime Minister, he offered the post of Foreign Minister to Shigenobu Okuma, the leader of the Progressive Party (another large political party in Japan). ${ }^{24}$ Indeed, the ruling government found itself in a crisis of leadership after the resignation of Prime Minister Ito in 1896, and commentators believed that the "Matsukata-Okuma coalition seems the only appropriate outcome of the crisis." 25 The press quipped that the Progressive party (which had previously spearheaded opposition to the government) now signaled their alliance with the Matsukata cabinet by "issuing a singularly tactless manifesto, in which they arranged for themselves the position of austere mentors. ${ }^{, 26}$ As Table 1 shows, the Progressive Party was a key player in the Diet and one of two parties that, along with the Liberals, often voted to block the legislation of the ruling party. ${ }^{27}$ More importantly, the Progressive Party was well represented on the House of Representatives Special

\footnotetext{
${ }^{23}$ Imperial Diet (1897) reprinted in Bank of Japan (1960, pp.129).

24 "Japanese Politics," London Times, December 4, 1896, p.8.

25 "Japanese Politics," London Times, December 4, 1896, p.8.

26 "Ministerial Changes in Japan," London Times, November 22, 1897, p.6.

${ }^{27}$ During his first term as Prime Minister (1891-92), Matsukata failed to get the support of Progressives and Liberals for the budget, which included finances for the building of warships. The failure of the budget resulted in his resignation (Masumi, 1966, pp.202-9 and 233-9).
} 
Committee on Monetary System to which the legislation was referred. Matsukata also bought off some Liberal party members, a subset of which established the New Liberal Party (Table 2). ${ }^{28}$

When the voting record and composition of the committee is examined more carefully, it is apparent that without the support of Progressives (who held the committee chair and made up 8 of the 26 voting members), the legislation would have stalled at the committee level. To verify the importance of Matsukata's alliance, we used a probit regression model of voting behavior. We regressed each committee member's vote on individual characteristics, including party affiliation (whether the member was part of the progressive-ruling party coalition), occupation (whether the member had served as a public servant), and district of representation (whether the member was from a silk growing region, the key export at this time). The coefficient on party (positive and statistically significant) suggests that committee members voted according to party affiliation (Table 3). With the support of the Progressives and some of the Liberals, the legislation narrowly passed 14 to 12 .

This coalition again proved sustainable when the debate moved out of committee and to the full Diet. Count Mutsu, Secretary for the Japanese legation in Washington, commented in American newspapers that the debate seemed to have already been won by the coalition in support of adoption: "In many instances the discussion [in the Diet] proceeded upon lines as far removed as well could be from the real point at issue." 29 The bill cleared the House of Representatives and the House of Lords and was proclaimed law on March $29^{\text {th }} .{ }^{30}$ The new currency act took effect on October $1,1897$.

\section{Section III. Did Gold Standard Adoption affect Interest Rates?}

\footnotetext{
${ }^{28}$ A contemporary reported that some 40 members from the Liberal Party were bought off by Matsukata's allies (Masumi, 1966, p.281).

29 “Japan's Gold Standard Law," Salt Lake Tribune, September 14, 1897.

${ }^{30}$ Not all the Progressives agreed with the government's position For example, Ukichi Taguchi, a famous free market economist and a member of Progressive Party had insisted that Japan should move toward the bimetallic standard. He made speeches opposing to the gold standard and voted against it. However, political commentators did not dispute the importance of the strategic alliance. When Count Okuma retired from the cabinet in November 1897, "the support of the political party led by him - namely, the Progressists - leaves the Government virtually without any adherents in the House of Representatives." ("Ministerial Changes in Japan," The (London) Times, December 29, 1897.) We were unable to locate the records of how individual Diet members voted, perhaps because the legislation was authorized with a simple voice vote or other majority consent procedure.
} 
The legislative and committee debates provide an understanding of why some policymakers looked favorably upon gold standard adoption for Japan. Many of the arguments made by policymakers in the 1890 s are quite similar to those who advocate fixed exchange rates today: the ability to tap international capital markets at lower rates of borrowing, reduced exchange-rate instability, and greater trade. We now turn to assessing the consequences of gold standard adoption in order to examine whether policymakers' ex ante beliefs about the effects of the gold standard were anticipated by market participants and whether they are consistent with realized outcomes. We begin with an assessment of the effects of gold standard adoption on sovereign bond yields.

\section{A. Evidence on Japanese Sovereign Debt from International Capital Markets}

One testable implication of committing to a policy rule such as the gold standard is that it should lower the cost of borrowing in international capital markets (Bordo and Kydland (1995) Indeed, Japan's adoption of the gold standard has been frequently cited as a canonical case of the potential beneficial effects of joining the gold standard, and contemporary media reports noted that this was the principal purpose of joining gold. ${ }^{31}$ Sussman and Yafeh (2000), for example, find that country risk of Japanese debt on the London market, defined as the current yield on a long-term Japanese bond minus the yield on the risk-free British consol declined more than fifty percent (or approximately 200 basis points) when the country joined the monetary rule in September 1897. They conclude that "the gold standard did significantly reduce the perceived risk associated with Japanese bonds (Sussman and Yafeh, 2000, p. 442). $" 32$

To carry out the empirical analysis of sovereign yield spreads, Sussman and Yafeh (2000) spliced the seven percent Japanese sterling bond issued in 1873 and paid off in 1897 with an unspecified long-

\footnotetext{
31 "It is supposed that the principal object the government has in bringing about the change is to enable it, should such a measure become necessary or expedient, to negotiate a loan in Europe on better terms than would be possible, as they believe, if Japan remained on a silver basis." (Japan's Gold Standard," The Sentinel, March 30, 1897.)

${ }^{32}$ Using the data set from Sussman and Yafeh, Tomita (2006, p.263) reaches similar conclusions. Related to our discussion, Tomita does note that it is difficult to draw inferences about risk spreads since the seven percent bond is maturing in 1897; however, he does not provide alternative series for analyzing the behavior of the Japanese risk premium.
} 
term bond issued in 1897 or thereafter. They argue that this is the best approach for testing the effect of adopting the gold standard on Japanese yield spreads since "data on domestic bond yields do not exist for Japan until the beginning of the twentieth century" (Sussman and Yafeh, 2000, fn 9, p. 446). Their unspecified debt series that begins in 1897 is most likely the War Loan Bond (fully redeemed by 1950), which had been underwritten by the Deposit Money Bureau (the Treasury Fund) in 1895-96 and resold in London in 1897 as the Imperial Japanese five percent bond of 1897 . We infer that this is the bond they used since it was the only debt issue actively traded on the London market that fits the time series plot shown in their paper. Figure 1 graphs these two bond series, where we have spliced them together as in their article. Using the current yield on the seven percent sterling loan and the five percent bond issue that appeared on the London market in October 1897, there appears to have been a dramatic fall in interest rates.

There are some problems with splicing the two different bond series, some of which were noted by Sussman and Yafeh (2002), but which we explore in greater detail in order to illuminate the discussion of how bond yields reacted to gold standard adoption. ${ }^{33}$ The Japanese government retired the seven percent sterling issue in the first half of 1897 and then sold new long-term five percent bonds that would be completely redeemed by 1950 in the second half of the year. ${ }^{34}$ Japan had long planned to retire the bond issue in 1897, which means that the drawing had no connection with the country's decision to join the gold standard except for the fact that the two events coincidentally took place in the same year (Ministry of Finance, 1904). Importantly, the redemption provisions of the seven percent debt issue placed a floor on interest rates of seven percent because investors knew that the bonds would be redeemed at par (where par=100) by April 1897. This means that the current yield provides little evidence about the Japanese cost of capital since bond market investors would necessarily take a capital loss if they purchased the seven percent bond at a price above par and paid the necessary transactions costs.

\footnotetext{
${ }^{33}$ See footnote 24 in Sussman and Yafeh (2000), p. 457.

${ }^{34}$ Bond markets investors were clearly aware ahead of time that the Japanese government intended to redeem the bond issue by April 1897. In the original contract at the primary issue in 1873, the Japanese government announced it would redeem the bond issue at par by 1897 (Ministry of Finance 1904, p.621). This information was reported in the Official Stock Exchange Intelligence (see Official Stock Market Intelligence, 1896, p. 215).
} 
An alternative test for measuring the effects of joining the gold club on Japanese country risk is to use a single bond issue that traded both before and after gold standard adoption. If one examines the Investors' Monthly Manual, the five percent Consolidated Loan bond was traded on the London Stock Exchange around the time of adoption. ${ }^{35}$ Not only is this bond quoted in London, this bond was originally issued in Tokyo and actively traded on the Japanese market. (Table 4 lists the bonds issued and/or listed in London during the sample period and discussed in this article.) It began trading in London July 1896 and had terms similar to the other bonds sold by the Japanese government on the British market in 1897. The Consolidated Loan bonds had a maturity length of 50 years and were callable after five years. The only significant difference between the Consolidated Loan and the War Loan Bond sold by the Japanese government immediately after gold standard adoption was that the War Loan Bond was endorsed to be paid in sterling. ${ }^{36}$ Matsukata's (1899) book on gold standard adoption confirms the existence of this domestic Consolidated Loan bond (Table L, p.378).

Figure 2 shows that, in the months prior to adoption, investors did not anticipate that the gold standard would lower future borrowing costs. Figure 2 also shows that country risk increased after adoption. In March 1897, the Consolidated Loan Bond traded at the average price of 105.5 pound with par value of 100 pounds. After the proclamation of the gold standard, the price dropped month by month to 95.875 pounds in August. In October, the price rebounded a little to 99.25 pound, but then continued its decline. It traded at 97 pound in December 1897.

\section{B. Evidence on Japanese Sovereign Debt from the Domestic Bond Market}

Contrary to what has been asserted in some previous studies of Meiji-era Japan (Sussman and Yafeh, 2000), an active and liquid market for domestic government bonds existed within Japan. From their inception in 1878, the Osaka and Tokyo stock exchanges listed both government bonds and

${ }^{35}$ This bond listed in the IMM as the "92-3-5 red" bond.

${ }^{36}$ Financial History of Meiji-Era, vol.8, National Debts (1904, p.837). 
company stocks. Prices and yields of bonds trading domestically can be used to clarify further whether Japan's adoption the gold standard had any effects on its borrowing costs.

From 1870-1896, the Japanese government issued seventeen bonds in the domestic market and two in the London Market. It also resold previously-issued domestic bonds twice in the London Market in 1896-97. In the late 1880 s and early 1890 s, the Japanese securities markets grew in volume and trading activity. Non-financial private investors more than doubled their securities holdings from 1886 to 1896. Japanese non-financial private sector ownership of financial assets increased from 265 million yen to 536 million yen between 1886 and $1896 .{ }^{37}$ The holdings of Japanese securities were widespread during our sample period. ${ }^{38}$

The Tokyo Stock Exchange (TSE) served as the central market in Japan. This market appears to have been well integrated with the rest of the world. Comparing the quotations for the Consolidated Loan bond in the London and Tokyo markets in Figure 2, we observe that the movements between the debt series are nearly identical. The minor differences between the interest rates probably reflect the fact that yields from the domestic Japanese market are computed from the average monthly bond price, while the yields for the London series are calculated from end-of-month prices reported in the IMM. Nevertheless, the Johansen Maximum Likelihood Procedure indicates that the null hypothesis of no cointegration can be rejected at the five-percent level of significance for the two interest rate series. ${ }^{39}$ The two Japanese bond price series share a common stochastic trend, suggesting that the London and Tokyo markets were integrated.

\footnotetext{
${ }^{37}$ In this section, figures of financial assets are from Fujino and Teranishi (2000).

${ }^{38}$ Private investors, including merchants and landowners, actively invested in domestic securities, and held large portions of government bonds and company stocks. As of the end of 1896, non-financial private investors owned 160-million-yen of government bonds (44 percent of the total outstanding) and 354-million-yen of company stocks (93 percent of total outstanding), while financial institutions owned 84-million-yen of government bonds and 27million-yen in equities (Fujino and Teranishi, 2000). Anecdotal evidence also suggests that merchants and landowners in the countryside as well as in the cities traded securities on an over the counter basis. For example, see Nakamura (2007).

${ }^{39}$ The estimated values for the $\lambda_{\text {MAX }}$ and $\lambda_{\text {TRACE }}$ test statistics were 15.20 and 17.12, respectively. Both the lambda max and lambda statistics indicate that the null hypothesis of no cointegration for yields of the Consolidated loan on the London and Tokyo markets can be rejected at the five percent level of significance.
} 
As of December 1896, TSE listed six government bonds, one municipal bond and 80 company stocks. Included in these domestically listed issues were two long-term bonds that traded actively on the Tokyo exchange before and after the country adopted the gold standard: (1) the previously mentioned five percent Consolidated Loan of 175 million yen that was sold at various dates between 1887 and 1895 and (2) the five percent War Loan of 125 million yen that was issued to help pay for the Japanese War with China in 1894-95. The two debt issues were to be redeemed in 1951 and 1910, respectively. Both issues paid interest in silver yen before the country adopted the gold standard in September 1897. After joining the monetary rule, the Japanese government began making interest payments on its domestic debt obligations in gold yen. This means that joining the gold standard could have also reduced exchange-rate risk, the risk associated with changes in the value of the currency, in addition to country or political risk.

Figure 3 shows the current yield for the two Japanese bond series from 1887-1910. The two series are highly correlated and do not seem to significantly decline with the introduction of the gold standard. Figure 3 suggests that domestic interest rates in Japan may have actually increased after the adoption of the gold standard. Nor do they seem to have fallen prior to formal adoption, which might suggest that investors were anticipating lower future borrowing costs. Simple summary statistics show that Japanese interest rates were more or less flat prior to adoption and increased by approximately 30 basis points in the six months after the country adopted the gold standard. ${ }^{40}$ We can gain some additional insight into whether investors were anticipating lower borrowing costs by examining reports from the investment community at that time. The Economist (p.879) wrote on June 19, 1897 that "the Japanese imagine that because they are adopting a gold standard currency their 5 per cent loans should command a higher price, but that they are trading below par (at 98 per cent) and "if any large amount were placed on the market there would soon be a considerable decline in the price." As a robustness check, Figure 4 shows the interest-rate differential between Japanese bonds and the "risk-free" British consol. The interest-rate

\footnotetext{
${ }^{40}$ Japanese interest rates increased by about 15 basis points in the six months prior to Japan joining the gold standard.
} 
differential should help control for the effect of gold inflation that began in 1897-98. Again, the Japanese yield spread does not appear to decline with the adoption of the gold standard. ${ }^{41}$

Finally, if adopting the gold standard was meant to improve Japan's reputation in capital markets and allow it to issue more debt, the period directly after adopting gold is very revealing. Confident with the victory of the Sino-Japanese war and the introduction of the gold standard, in 1899 the government floated a new $¥ 100$ million bond issue in London. It sold at 90 percent of par with a current yield of 4.45 percent - a much higher interest rate than predicted by Matsukata and the Japanese authorities. The Japanese government then purchased much of the outstanding issue at 86 percent of par, an even deeper discount with a yield of $4.65 \%$ (Suzuki, 1994). If we also account for the fact that the bonds were denominated in sterling, which reduced exchange rate risk, then the new debt issue offered about the same yield (4.8\%) as the yen-denominated consolidated bonds that traded in London. Moreover, this debt issue met with tepid response from foreign investors. Less than 10 percent of the primary issue was purchased in the London market. The Japanese government (with assistance from the Bank of Japan) responded by purchasing nearly 45 percent of the issue, with the underwriters having to absorb the remainder. Japan had believed its credit rating, after adopting gold was "between Germany and Italy," but according to Suzuki (1994) and Metzler (2006), it had overestimated its creditworthiness in foreign markets and later additional attempts to engage foreigners in purchasing these bonds (including attempts by J.P. Morgan and Co., Baring Brothers, and the Rothschilds) were rebuffed by investors.

Furthermore, archival evidence suggests that if, anything, the reason why Japan issued little debt in the 1880 s and early 1890 s had more to do with fear of being colonized by foreign creditor governments than it did with not being on gold. For example in July 1880, Former Finance Minister Shigenobu Okuma and former Internal Minister Hirobumi Ito jointly proposed the establishment of "the specie bank," which

\footnotetext{
${ }^{41}$ We formally tested this hypothesis using structural break analysis and following the procedure developed by Zivot and Andrews (1992). The structural break tests for yield spreads and interest rates over the sample period 1892-1902 are not statistically significant at the five- or ten-percent level of significance. We also tested for a structural break over the entire sample period 1887-1910 and found no evidence that the gold standard significantly reduced interest rates. We also are not able to reject the null hypothesis of a unit root in favor of a structural break model. Results are available from the authors upon request.
} 
would be the Japanese equivalent of the Bank of England or the Bank of France. To this end, they proposed to issue a government bond which would be salable to foreign investors. ${ }^{42}$ Fearing foreign control in Japanese affairs, Internal Minister Matsukata strongly opposed this idea, writing in September, "We are now in a vulnerable position without having the independence of tariff and justice. If we depended on capital of foreigners, who are superior in knowledge and financial power, we should be in a big trouble even though we might see a temporary inflow of specie. We would have nothing to do when Japan should be a country like Egypt, Turkey or India. ${ }^{, 43}$ Matsukata turned down the proposal, and two years later, as finance minister, he established the Bank of Japan, which was purely domestic.

\section{Section IV. How did Gold Standard Adoption affect Trade?}

As identified by the parliamentary debates and the Committee on the Monetary System, policymakers also believed that trade would be impacted by the adoption of the gold standard, but there was considerable disagreement as to how it would affect trade. Some believed that maintaining the silver standard was beneficial to trade as it enabled Japan to sell its exports more cheaply to gold standard countries. Others argued that adopting gold would be beneficial for trade as it would lower exchange-rate volatility and transaction costs. Other policymakers noted that the gains from being on silver were transitory, based on a favorable silver-gold price that would not persist, and that going on gold would at least permit Japan to trade among a global trade network that was organized around gold and not silver.

To test these three hypotheses, we estimate a gravity model of Japan's bilateral export flows during the late nineteenth and early twentieth centuries. We collected data on bilateral trade flows between Japan and other countries from the Principal Trade of Foreign Countries of the British Board of Trade Statistics and from Japan's Ministry of Finance, Annual Return of the Foreign Trade of the Empire of Japan. These two primary sources contain more than 800 observations on Japanese bilateral trade flows with twenty-six of its main trading partners for the years 1877-1912. The sample contains data on

\footnotetext{
${ }^{42}$ Okuma (1880).

${ }^{43}$ Matsukata (1880).
} 
bilateral flows between Japan and countries from Asia, Europe, North and South America including: Australia, Canada, China, England, French Indochina, Hawaii, Hong Kong, India, Korea, New Zealand, Philippines, Siam, Straits Settlement, Austria, Belgium, Denmark, France, Germany, Italy, Netherlands, Peru, Portugal, Spain, Switzerland, Russia, Turkey, and the United States.

A gravity model is a very simple empirical relationship meant to capture the main effects of trade: mass and distance. As in a standard gravity equation, mass (measured here by the size of countries) is proportional to trade whereas distance should vary inversely. Given that we do not have GDP estimates for many of the dyadic trade pairs in our sample, we use population as a proxy for mass which has been shown to have a correlation of nearly ninety percent with output estimates for the classical gold standard period (Mitchener and Weidenmier, 2007).

We augment the gravity equation with additional covariates which are meant to capture other influences on bilateral trade. We include railroad track miles to proxy for the importance of transportation infrastructure in promoting bilateral trade flows. We include a dummy variable to indicate whether Japan's trading partner is landlocked. Since some studies have indicated that war negatively impacts trade flows (Glick and Taylor, 2006), a war indicator variable is included to take into account the fact that Japan fought two wars during our sample period. The indicator variable takes on a value of 1 when Japan was at war with China (1894-95) or Russia (1904-05) for those respective dyads. We also code a Most Favored Nation (MFN) dummy variable as unity in cases where Japan has a reciprocal MFN arrangement (or in Korea and China where it imposed unilateral agreements during our sample period).

The basic estimation equation is:

(1) $\ln \left(\right.$ EXPORTS $\left._{\mathrm{it}}\right)=\beta_{0}+\beta_{1}$ PaperBimet $_{\mathrm{it}}+\beta_{2}$ PaperPaper $_{\mathrm{it}}+\beta_{3}$ PaperGold $_{\mathrm{it}}+\beta_{4}$ SilverSilver $_{\mathrm{it}}+$ $\beta_{5}$ GoldGold $_{\text {it }}+\beta_{6}$ SilverGold $_{\text {it }}+\beta_{7}$ SilverPaper $_{i t}+\beta_{8}$ GoldPaper $_{\text {it }}+\beta_{9}$ GoldSilver $_{i t}+\beta_{10}$ MFN $_{\text {it }}+\beta_{11} \ln (\text { Dist })_{\mathrm{i}}$ $+\beta_{12} \operatorname{Lndlck}_{\mathrm{i}}+\beta_{13} \ln \left(\mathrm{RR}_{\mathrm{i}}\right)_{\mathrm{t}}+\beta_{14} \ln \left(\operatorname{Pop}_{\mathrm{i}} \mathrm{Pop}_{\mathrm{j}}\right)_{\mathrm{t}}+\beta_{15} \mathrm{War}_{\mathrm{i}, \mathrm{t}-\mathrm{k}}+\varepsilon_{\mathrm{it}}$

where $\mathrm{i}$ denotes a trade partner of Japan, $\mathrm{j}$ denotes Japan, $\mathrm{t}$ denotes time, $\mathrm{k}$ denotes lags, and other variables are defined as: 
- EXPORTS $_{\text {it }}$ denotes Japanese exports to country $\mathrm{i}$ at time $\mathrm{t}$;

- PaperBimet is a binary variable which is unity if Japan is on the paper standard and country i is on the bimetallic standard.

- PaperPaper is a binary variable which is unity if country $i$ and Japan are both on a fiat money standard.

- PaperGold is a binary variable which is unity if Japan is on a fiat money standard and country $i$ is on the gold standard.

- SilverSilver is a binary variable which is unity if country $\mathrm{i}$ and Japan both are on the silver standard;

- GoldGold is a binary variable which is unity if country $i$ and Japan are both on the gold standard;

- SilverGold is a binary variable which is unity if Japan is on the silver standard and country $i$ is on the gold standard.

- SilverPaper is a binary variable which is unity if Japan is on the silver standard and country $i$ is on a fiat money standard.

- GoldPaper is a binary variable which is unity if Japan is on the gold standard and country $i$ is on a fiat money standard.

- GoldSilver is a binary variable which is unity if Japan is on the gold standard and country $i$ is on the silver standard.

- MFN is a binary variable that takes a value of 1 if Japan has negotiated a reciprocal most favored nation treaty with a trade partner or if it has imposed a unilateral MFN on a trade partner that is in effect at time $t$.

- Dist is distance between Japan and country i;

- Lndlck is a binary variable which is unity if Japan's trade partner is landlocked;

- $\quad \mathrm{RR}$ is railroad track miles;

- Pop is population;

- War is a binary variable which is unity for Japanese exports to China during the Sino-Japanese War (1894-95) and unity for Japanese exports to Russia during the Russo-Japanese War (1904$05)$;

- and $\varepsilon$ is a well-behaved error term capturing other influences on bilateral trade.

The coefficients $\beta_{1}-\beta_{9}$ measure the effects of Japan's various monetary standards on bilateral trade flows. The gold and silver dummy variables, SilverSilver and GoldGold, capture the network externalities associated with Japan first adopting silver and being on the same currency regime as other silver standard countries, and then later adopting gold and sharing that currency regime with other countries. If membership in the same monetary standard reduces transactions costs or exchange rate volatility, then the coefficients on the SilverSilver and GoldGold dummy variables should be positive and statistically significant. By coding additional dummy variables reflecting the currency arrangements of all its trading partners, not just those with which it shared the standard, we can simultaneously test for the other hypotheses that follow from the historical debates of gold standard adoption. In particular, the pairs 
SilverGold and GoldSilver enable us to determine whether Japan's exports benefitted from movements in the price of silver relative to gold. While Japan was on the silver standard, this metal was depreciating relative to gold, so as argued by some legislators and exporters, Japan may have received a boost in its trade to gold standard countries as a result of this price movement. (This would be reflected in a positively signed and statistically significant coefficient on SilverGold.) Then, about the time when Japan joined the gold standard, gold began to depreciate against silver; so once Japan was on gold its exports to silver countries may have been more competitive, and hence higher.

We estimate equation (1) with importer-country fixed effects as well as year dummies to control for annual shocks such as global financial crises and recessions. The fixed-effects or within estimator is equivalent to adding a complete set of country-pair intercepts to the estimating equation. Our first regression specification, shown in column 1 of Table 5, uses the paper standard as a basis of comparison; hence, the omitted dummy variable is when Japan was on the paper standard and other countries were on the silver standard (in our nomenclature, PaperSilver). Using this specification, we can directly assess the impact of switching from a fiat standard to a commodity exchange-rate regime. Since many of Japan's most important trading partners historically were on silver, this specification allows us to examine whether there were gains to adopting the same standard as its neighbors on silver, such as China and Korea. Conditioning on other variables, when Japan switched from paper to silver and its trade partner was also on silver (SilverSilver), exports received a boost of over 1,094 percent $\left(\left(e^{2.48}-1\right)^{*} 100\right)$. This positively signed and statistically significant (at the one-percent level) network externality effect suggests that there were initially large gains to moving to the same monetary standard as its regional trade partners; it reduced exchange rate volatility and lowered transactions costs.

When Japan then switched to gold and traded with other gold standard countries, bilateral trade flows increased by approximately 953 percent (relative to the baseline of PaperSilver). (The effect is statistically significant at the five-percent level.) The switch to the silver standard also appears to have raised Japan's exports to gold standard countries (SilverGold), and its subsequent adoption of gold appears to have then raised exports to silver standard countries. When Japan was on the silver standard 
and its trade partner was on gold, exports increased by 860 percent. ${ }^{44}$ Hence, advocates of the silver standard were correct in emphasizing that Japan had received an enormous boost in its trade due to the depreciation of silver when it was on the silver standard. This statistically significant effect is consistent with policymakers' beliefs of what had occurred prior to 1897: Japan's manufacturing exports benefitted from the decline in the relative price of silver. However, when Japan was on the gold standard and its trade partner was on silver, exports increased by 1525 percent. Hence, proponents of going to gold were also correct in that Japan's exports did not lose out on their competitive advantage with the switch from silver to gold, although perhaps more out of luck than out of perfect foresight. That is, gold began to depreciate against silver at about the same time that Japan joined the gold standard. If Japan had remained on silver until 1913, it would not only have seen its competitiveness deteriorate, but it would also have lost out on the gain in competitiveness form gold's depreciation relative to silver. Overall, these statistically significant coefficients suggest that relative to initially being on a fiat standard, a substantial part of the gains from trade from going onto either gold or silver had to do with the movement in the silver-gold price ratio and the competitiveness effects associated with this movement.

Our other policy and institutional variables, trade agreements (MFN) and war dummies, are not statistically significant at conventional levels. In terms of our other covariates, distance from Japan has a strong negative impact and strong transportation networks in importing countries (proxied by railways) increased Japanese exports. Although population has a negative and statistically significant effect on exports, the unconditional correlation between $(\log )$ exports and population is positive, but not statistically significantly different from zero. ${ }^{45}$

The second column of Table 5 uses a slightly different baseline for comparison so that we can more carefully consider the network externality effects of moving from the silver standard to the gold

\footnotetext{
${ }^{44}$ Metzler (2006) also suggests Japan saw an increase in trade when it was on the silver standard, although he does not provide a formal test as we do here.

${ }^{45}$ When use a median regression model for exports, we find that population has a positive sign, but is insignificant at conventional levels of statistical significance.
} 
standard. In this regression, the omitted category is SilverSilver. ${ }^{46}$ The sign on GoldGold is positive, but statistically insignificant, suggesting that the gains from being part of the gold club were not substantially larger than those when Japan was on silver. ${ }^{47}$ This coefficient suggests that there was no differential impact in terms of a network effect relative to the silver standard's network effect. ${ }^{48}$ So if adopting gold did not raise Japanese exports (relative to the network externality effects of the silver standard), then did Japanese trade receive any benefits from gold standard adoption?

The answer may lie in Japan's growing share of global trade coming from gold standard countries. By the late 1890s, most of the world's largest economies were on gold (U.S., UK, and Germany) and much of the rest of the world was abandoning bimetallic, silver, and paper standards for gold (Meissner, 2005). For example, Austria pegged its currency to gold in the mid-to-late 1890s, Russia joined gold in 1897, India joined gold in 1898, and Argentina adopted in 1900. The benefits to remaining on silver, even in Asia, were declining as the world moved to gold (Mitchener and Voth, 2009). Hence, as the $19^{\text {th }}$ century drew to a close, the longer Japan remained on silver, the smaller the benefit it would receive by being linked to the same monetary regime of its historical and regional trading partners (silver countries such as China and Korea). The network effect of silver was strong for Japan (as demonstrated by the statistically insignificant coefficient on GoldGold in column 2), but as emphasized by contemporary policymakers like Sakatani, Japan's trade was turning outward, beyond Asia, to a world that was increasingly dominated by the gold standard. By 1897, nearly 60 percent of all Japanese exports and trade were conducted with gold standard countries in 1897. In comparison, silver accounted for approximately 30 percent of exports and 35 percent of total trade flows.

\section{Did the Gold Standard Create an Investment Boom?}

\footnotetext{
${ }^{46}$ The change in the omitted category means that we now include SilverPaper in the regression.

${ }^{47}$ The constant term in the regression is large, positive and statistically significant at the 1 percent level, suggesting that network externality of effect of silver was large.

${ }^{48}$ Consistent with the regression results in column 1, Japan's trade was lower when it was on paper and traded with silver countries, suggesting the strong network externality effect of being on the silver standard.
} 
Some Japanese policymakers also believed that joining the gold standard could initiate a domestic investment boom. Adherence to the monetary rule would lower domestic interest rates, leading firms to invest in new plant and equipment (due to lower overall borrowing costs in the economy). Declining interest rates may also precipitate a run up in stock prices as stocks become relatively more attractive in comparison to bonds.

To examine the investment-boom hypothesis, we first gathered new monthly data on Japanese stock prices around the time of gold standard adoption from the archives of the Tokyo Stock Exchange. Based on data for stocks listed and actively traded on the Tokyo exchange, we calculated a monthly capitalized market index of 13 companies for the period 1895-1899. The index represents approximately 70 percent of the capitalized market value of the Japanese stock exchange. ${ }^{49}$ If expected profitability of Japanese companies improved in anticipation of gold standard adoption or after gold standard adoption, then this should have been capitalized into stock prices, and our composite index should show an increase after the time of adoption.

However, as Figure 5 shows, the data do not support the idea that the gold standard created an investment boom that led to higher profitability of Japanese firms. The Japanese stock market index increased in the beginning of the sample period before declining by more than 35 percent in the one-year period before Japan joined the gold standard. This suggests that investors did not anticipate higher expected future profitability as a result of adoption. The stock market index then fell by an additional ten percent in the year after Japan joined the gold standard, suggesting that, after adoption, investors perceived that firms were not large beneficiaries of a dramatically lower of interest rates. As a robustness check, we also calculated an unweighted stock market index for the period. As shown in Figure 6, the unweighted stock market index declined more than 30 percent after gold standard adoption. Bank of Japan reported that the stock market remained dull throughout 1897 , including the period prior to and after the adoption of the gold standard. It said, "The stock market in 1897 was dull in general. While the

\footnotetext{
${ }^{49}$ Although it is possible that the increase in bilateral trade flows might have led to a surge in domestic investment, most of the firms included in our stock sample were involved in domestic finance and transport - railway companies building passenger railways.
} 
adoption of the gold standard brought a temporary boom to the stock market, investors held still after all because they had a feeling of anxiety for the future. In March, stock prices surged because the passage of the New Currency Act brought a speculation of capital inflow in the future. But, it did not last for a month, and the market turned dull in early April." Commentators noted that the decline in security prices reflected a general feeling of uncertainty in the business community following gold standard adoption. ${ }^{50}$

Contemporaries reported that the adoption of the gold standard did not expand the borrowing capacity of Japan nor did it bring about a domestic investment boom. Japanese newspaper accounts written at the end of 1897 generally condemned the gold standard. The Jiji Shinpo called adoption of gold, "the worst mistake ever committed by the government in the long history of the 30 years that have passed since the Meiji era began. The Matsukata ministry, however, must bear the full responsibility for it." ${ }^{, 51}$ Newspapers generally acknowledged that "the financial situation in Japan is worse than it was in 1896. Public securities have fallen; railway and industrial shares are very low, and many new undertakings have stopped for lack of funds...Foreign capital has not come in, neither have the public securities appreciated. ${ }^{, 52}$ On December 14, 1897, the nationwide newspaper, Yomiuri Shinbun, quoted prominent economist, Tameyuki Amano, as describing the current economic condition as a combination of insufficient capital and falling prices of stock and goods in general. He attributed the stagnating economy to lack of credibility of the Japanese economy among the international investors and the absence of capital inflow in spite of the adoption of the gold standard. The Yomiuri Shinbun also reported in December 1897 that adoption of gold may have led to a financial panic in Osaka - news that was also reported by the American press. ${ }^{53}$ On August 5, 1898, the Yomiuri Shinbun reported that even though a number of railway companies had tried to attract foreign investment, none had succeeded. On October 19, 1898, the newspaper further commented that investment in Japan was not attractive for international

\footnotetext{
${ }^{50}$ Droppers (1898, p.177).

51 The views of Japanese newspapers were summarized in the following article: "Japan and her Gold Standard," Denver Evening Post, March 2, 1898.

52 "Japan and her Gold Standard," Denver Evening Post, March 2, 1898.

53 See, for example, “Gold Standard Panic in Japan,” Daily News, Denver, December 17, 1897, p.5.
} 
investors mainly because of lack of credibility despite the fact that Japan had been on gold for more than a year.

Policymakers also saw no boom in the Japanese economy. The annual report of Bank of Japan in 1897 said, "in light of larger expectation of capital inflow to Japanese markets, prominent investors from the United States and France came to Japan to explore the feasibility of investments. But, they returned home with no achievement for their goal." The report in 1898 continued, "some (international) investors tried to launch new projects for foreign capital introduction into Japan, but all attempts failed... The government explored the feasibility of issuing bond in the foreign markets as well as in the domestic markets, but they were not able to do so. They were forced to finance the deficit by the remaining balance of Chinese indemnity." Clearly, Japan was failing to attract foreign capital or create an investment boom by adopting the gold standard..$^{54}$

In order to assess further whether an investment boom occurred after gold standard adoption, we collected data on the investment-GNP ratio. We compared the average investment-GNP ratio for the fiveyear period before Japan (1893-1897) joined the gold standard with the five-year period after Japan joined gold (1898-1902). We chose to end the "gold standard effect" in 1902 since some scholars have noted that the Russo-Japanese War (1904-05) enhanced the country's international standing and credibility (Metzler, 2006; Sussman and Yafeh, 2000). The average investment-GNP ratio was actually higher in the five-year period before Japan joined the gold standard than afterwards (17.1 versus 16 percent). As a robustness check, we dropped the value of the ratio for 1897 from the pre-gold period (since Japan voted to join gold in March but did not formally adopt the monetary rule until September) and recomputed the investmentGNP ratio in the five-year period before and after 1897. The investment-GNP ratio is slightly higher when Japan was on the silver standard than after it went on gold: 16.3 versus 16 percent. ${ }^{55}$ Overall, the

\footnotetext{
${ }^{54}$ Bank of Japan (1898, 1899).

${ }^{55}$ As a robustness check, we also compared the silver period 1888-1897 with the gold period 1898-1902 as well as the silver period 1896-97 with the gold period 1898-1899. In all cases, we could not statistically reject the null hypothesis that joining the gold standard had no effect on the investment-GDP ratio.
} 
empirical evidence suggests that joining the gold standard did not stimulate a boom in the Japanese equity market or in investment spending.

\section{Conclusion}

This paper argues that in order to understand the reasons why countries adopted monetary standards and the consequences this choice had on their economies, it is helpful to begin the analysis by considering the political economy of the adoption decision. Interest groups may not be aligned (as their objective functions may differ) and outcomes may be uncertain. Examining countries adoption decisions on a case-by-case basis, as we do in this paper, enables the researcher to design empirical tests that are based on the ex ante beliefs of policymakers and to measure investor perceptions of adoption as well as the effects of adoption on multiple economic outcomes.

Our examination of the historical record suggests that a priori policymakers were split over of Japan's decision to join the gold standard in 1897. Many influential business leaders, academics, and government officials emphasized that adopting gold as the monetary standard would significantly impact trade, but they disagreed over whether it would be beneficial or detrimental. Some, like Matsukata, argued that it would increase exports because other countries were moving to gold and that Japan would have less exchange-rate volatility and lower transaction costs if it too were on gold. Others argued that it would prematurely terminate the benefits of being on silver: the declining price of silver since 1870 had been lowering the relative price of Japanese exports and many of Japan's most important trading partners were on the silver standard. Other policymakers encouraged Japan to adopt the gold standard for different reasons - that it would be perceived by markets as a move towards better institutions and would hence lower Japan's borrowing costs. Prime Minister Matsukata, however, forged a successful coalition with a rival party to overcome opposition to the legislation.

Investors, however, did not seem to be swayed that gold standard adoption would have lasting effects on either borrowing costs or domestic investment. Using newly assembled data on asset prices, we show that stock prices and government bonds did not move in anticipation of gold standard adoption. We 
further show that Japan's adoption of the gold standard did not lower Japan's borrowing costs nor lead to a surge in domestic investment. Based on evidence from both international and domestic capital markets, if anything, there was a slight increase in the rates of borrowing after adoption. These findings suggest a reinterpretation of Meiji financial history since previous studies had associated a reduction in borrowing costs with gold standard adoption. While it is theoretically possible that a hard peg can serve as a mechanism for solving the time inconsistency problem, the case of Japan does not appear to be the canonical case study of such a mechanism.

Instead, Japan's experience suggests that metallic standards had a much more significant effect on exports. Estimates from gravity models show that exports increased when Japan went onto both the silver and gold standards. Our results suggest that Japan received a large boost to its bilateral trade when it was on the silver standard both through network externalities and via competitiveness effects: the declining of silver relative to gold boosted exports to gold standard countries. Nevertheless, Japan's adoption of the gold standard proved to be fortuitously timed as the decline in silver prices reversed course at around the same time Japan made the switch to gold and when the rest of the world was moving to the gold standard. We find evidence that when Japan was on the gold standard its exports to other gold countries were higher, relative to the reference period of paper, and that its trade with silver countries benefitted due to the decline in the price of gold. If Japan had remained on the silver standard it would have necessarily foregone a large gain in the competitiveness of its exports (something that was not known to policymakers ex ante) and faced a declining benefit via network externalities as more and more countries adopted gold. The political economy approach that we have used to study Japan's adoption decision has shed new light on the reasons for and consequences of adoption, and suggests a robust alternative to the cross-country approach that could be employed to examine the adoption of gold for other countries during the classical gold standard era. 


\section{References}

Bank of Japan. (1898). "Meiji 30 Nen Nippon Ginko Tokei Nenpo" [Statistical Abstract of Bank of Japan, 1897], reprinted in Bank of Japan (1957), Nihon Kin’yu Shi Shiryo: Meiji/Taisho Hen, vol.19 [Materials of Japan's Financial History: Meiji/Taisho Edition], vol.19, pp. 279-326.

Bank of Japan. (1899). "Meiji 31 Nen Nippon Ginko Tokei Nenpo" [Statistical Abstract of Bank of Japan, 1898] reprinted in Bank of Japan (1957), Nihon Kin’yu Shi Shiryo: Meiji/Taisho Hen [Materials of Japan's Financial History: Meiji/Taisho Edition], vol.19, pp. 327-366.

Bordo, Michael and Finn Kydland. (1995). "The Gold Standard as a Rule: An Essay in Explorations." Explorations in Economic History vol. 32(4) pp. 423-64.

Bordo, Michael and Hugh Rockoff. (1996). "The Gold Standard as a Good Housekeeping Seal of Approval” Journal of Economic History vol. 56 pp. 389-428.

Bytheway, Simon. (2001). "Japan's adoption of the Gold Standard: Financial and Monetary Reform in the Meiji Period." In John McGuire, Patrick Bertola, and Peter Reeves (eds.) Evolution of the World Economy, Precious Metals and India. Oxford: Oxford University Press, pp.79-95.

Christiano, Lawrence (1992). "Searching for a Break in GNP." Journal of Business and Economic Statistics vol. 10 pp. 237-50.

Committee on the Monetary System. (1895). "Final Report,"reprinted in Bank of Japan (1957), Nihon Kin’yu Shi Shiryo: Meiji/Taisho Hen, [Materials of Japan's Financial History: Meiji/Taisho Edition], 17.

Droppers, Garrett. (1898). “Monetary Changes in Japan.” Quarterly Journal of Economics 12(2): 153-185.

Ferguson, Niall and M. Schularick. (2006a). "The Empire Effect: The Determinants of Country Risk in the First Era of Globalization." Journal of Economic History vol. 66(2) pp. 283-312.

Ferguson, Niall and M. Schularick. (2006b). "The Thin Film of Gold: The Limits of Monetary Commitments." Harvard Business School Working Paper.

Flandreau, Marc and Mathilde Maurel. (2005). "Monetary Union, Trade Integration, and Business Cycles in the $19^{\text {th }}$ Century." Open Economies Review vol. 16(2) pp. 135-52.

Flandreau, Marc and Frederic Zúmer. (2004). The Making of Global Finance. Paris: OECD.

Fujino, Shozaburo, and Juro Teranishi. (2000). Nihon Kin'yu no Suryo Bunseki [A Quantitative Analysis of Finance in Japan], Toyo Keizai Shinpo Sha.

Glick, Reuven and Alan M. Taylor (2006). Collateral Damage: Trade Disruption and the Economic Impact of War," NBER Working Paper 11565.

Harada, Keiichi. (2007). Nisshin-Nichiro Senso: Nihon Kin-Gendai Shi, [Sino/Russo-Japanese War: Modern and Contemporary Japanese History], 3, Iwanami Shoten.

Imperial Diet. (1897). "Teikoku Gikai Sokkiroku: Dai-Jukkai Teikoku Gikai” [Minutes of General Assembly and Committees of the $10^{\text {th }}$ Session], reprinted in Bank of Japan (1960), Nihon Kin'yu Shi Shiryo: Meiji/Taisho Hen, 14 [Materials of Japan's Financial History: Meiji/Taisho Edition], 14.

Kydland, Finn and Edward Prescott. (1985). "Rules Rather than Discretion: The Inconsistency of Optimal Plans." Journal of Political Economy vol. 85(3) pp. 473-91. 
Laughlin, J. Laurence. (1897). “The Gold Standard in Japan.” Journal of Political Economy 5(3): 378-83.

Lopez-Cordova, J. Ernesto and Christopher Meissner. (2003). "Exchange-Rate Regimes and International Trade: Evidence from the Classical Gold Standard Era." American Economic Review vol. 93(1) pp. 344-53.

Masumi, Jun'nosuke. (1965). Nihon Seito-Shi Ron [A Thesis on the History of Japanese Political Party System] vol. I, University of Tokyo Press.

Masumi, Jun'nosuke. (1966). Nihon Seito-Shi Ron [A Thesis on the History of Japanese Political Party System] vol. II, University of Tokyo Press.

Matsukata, Masayoshi. (1880). "Zaisei-Gi” [On Financial Policy], reprinted in Bank of Japan (1958), Nihon Kin'yu Shi Shiryo: Meiji/Taisho Hen, 4 [Materials of Japan's Financial History: Meiji/Taisho Edition], 4, pp. 983-988.

Matsukata, Masayoshi. (1899). Report on the Adoption of the Gold Standard in Japan, Tokyo, the Government Press.

Mauro, Paolo, Nathan Sussman and Yishay Yafeh. (2006). Emerging Markets and Financial Globalization. Oxford: Oxford University Press.

Metzler, Mark. (2006). Lever of Empire: The International Gold Standard and the Crisis of Liberalism in Prewar Japan. Berkeley: University of California Press.

Meissner, Chris. (2005). "A New World Order: Explaining the International Diffusion of the Gold Standard, 1870-1913.” Journal of International Economics. 66: 385-406.

Miller, Edward S. (2007). Bankrupting the Enemy: The U.S. Financial Siege of Japan Before Pearl Harbor. Annapolis, MD: Naval Institute Press.

Ministry of Finance. (1904). Meiji Zaisei Shi, 8: Kokusai [Financial History of the Meiji-Era, 8: National Debts].

Ministry of Finance. (1905). Meiji Zaisei Shi, 11: Tuka [Financial History of the Meiji Era, 11: Money].

Ministry of Finance; Financial Bureau. (1898). "Kahei-Hou Seitei oyobi Jisshi Houkoku" [The Report on the Legislation of the Currency Act and its Implementation], reprinted in Bank of Japan (1958), Nihon Kin'yu Shi Shiryo: Meiji/Taisho Hen, 17 [Materials of Japan's Financial History: Meiji/Taisho Edition], 17, pp. 1-289.

Ministry of Finance. (1898). "Meiji 30 Nen Heisei Kaikaku Shimatsu Gaiyou" [The Overview of the Reform of the Monetary System in 1899], reprinted in Bank of Japan (1958), Nihon Kin'yu Shi Shiryo: Meiji/Taisho Hen, 17 [Materials of Japan's Financial History: Meiji/Taisho Edition], 17, pp. 291-558.

Mitchener, Kris James and Hans Joachim Voth. (2009). "Trading Silver for Gold: Asian Exports and the Political Economy of Currency Unions." Unpublished Working Paper prepared for the Asian Development Bank.

Mitchener, Kris James and Marc D. Weidenmier. (2007). "Trade and Empire," Santa Clara University Working Paper.

Muramatsu, Michio, Mitsutoshi Ito, and Yutaka Tsujinaka. (2001). Nihon no Seiji [Japanese Politics], $2^{\text {nd }}$ edition, Toyo Keizai Shinpo Sha.

Murase, Shinya (1976). "The Most-Favored Nation Treatment in Japan's Treaty Practice during the Period, 1854-1905.” American Journal of International Law vol. 70(2) pp.273-297. 
Nakamura, Naofumi. (2007). "Meijiki no Yuka Shoken Toshi (Securities Investments in Meiji Era)," Ishii, Kanji and Satoru Nakanishi eds., Sangyoka to Shoka Keiei [Industrialization and the Family Merchant Business], Nagoya University Press.

Obstfeld, Maurice and Alan M. Taylor. (2003). "Sovereign Risk ,Credibility and the Gold Standard, 1870-1913 versus 1925-1931.” Economic Journal vol. 113 (487) pp. 1-35.

Official Stock Market Intelligence. Various years. London.

Okuma, Shigenobu. (1880). "Kousai Shinbo oyobi Ginkou no Setsuritu ni Kansuru Seigi” [An Proposal for A New Government Bond Issue and the Establishment of A Bank], reprinted in Bank of Japan (1958), Nihon Kin'yu Shi Shiryo: Meiji/Taisho Hen, 4 [Materials of Japan's Financial History: Meiji/Taisho Edition], 4, pp. 754-756.

Shimura, Kaichi. (1980). Nihon Koushasai Shijou Shi [A History of Bond Markets in Japan], Tokyo, University of Tokyo Press.

Sussman, Nathan and Yishay Yafeh. (2000). "Institutions, Reforms and Country Risk: Lessons from Japanese Government Debt in the Meiji Period," Journal of Economic History vol. 60 pp. 442-67.

Suzuki, Toshio. (1994). Japanese Government Loan Issues on the London Capital Market, 1870-1913, London, The Athlone Press.

Tokyo Stock Exchange. (1928). Tokyo Kabushiki Torihikijo 50 Nenshi [50 years History of Tokyo Stock Exchange], Tokyo, Tokyo Stock Exchange.

Tomita, Toshiki. (2006). Kokusai no Rekishi [A History of National Debts], Tokyo, Toyo Keizai Shinpo Sha.

Zivot, Eric and Donald Andrews. (1992). "Further Evidence on the Great Crash, Oil Price Shock, and the Unit Root Hypothesis.” Journal of Business and Economic Statistics vol. 10 pp.251-70. 
Table 1. Composition of the House of Representatives, September 1896

(Lower House of Diet)

\begin{tabular}{lcccl} 
& Party Affiliation & & Strategic Voting & Name of Bloc \\
\cline { 2 - 3 } $\begin{array}{l}\text { People's Association } \\
\text { others/independent }\end{array}$ & 52 & & $\begin{array}{l}\text { Government-oriented } \\
\text { parties }\end{array}$ \\
\hline Progressive Party & 99 & 99 & Strategic alliance \\
\hline Liberal Party & 111 & 111 & Opposition party \\
\hline Total & 299 & &
\end{tabular}

Source: House of Representatives and House of Peers,

Gikai Seido Nanaju Nen Shi [Seventy Years History of Parliamentary System], 1961. 
Table 2. Members of the Special Committee on Monetary System, House of Representatives (1897)

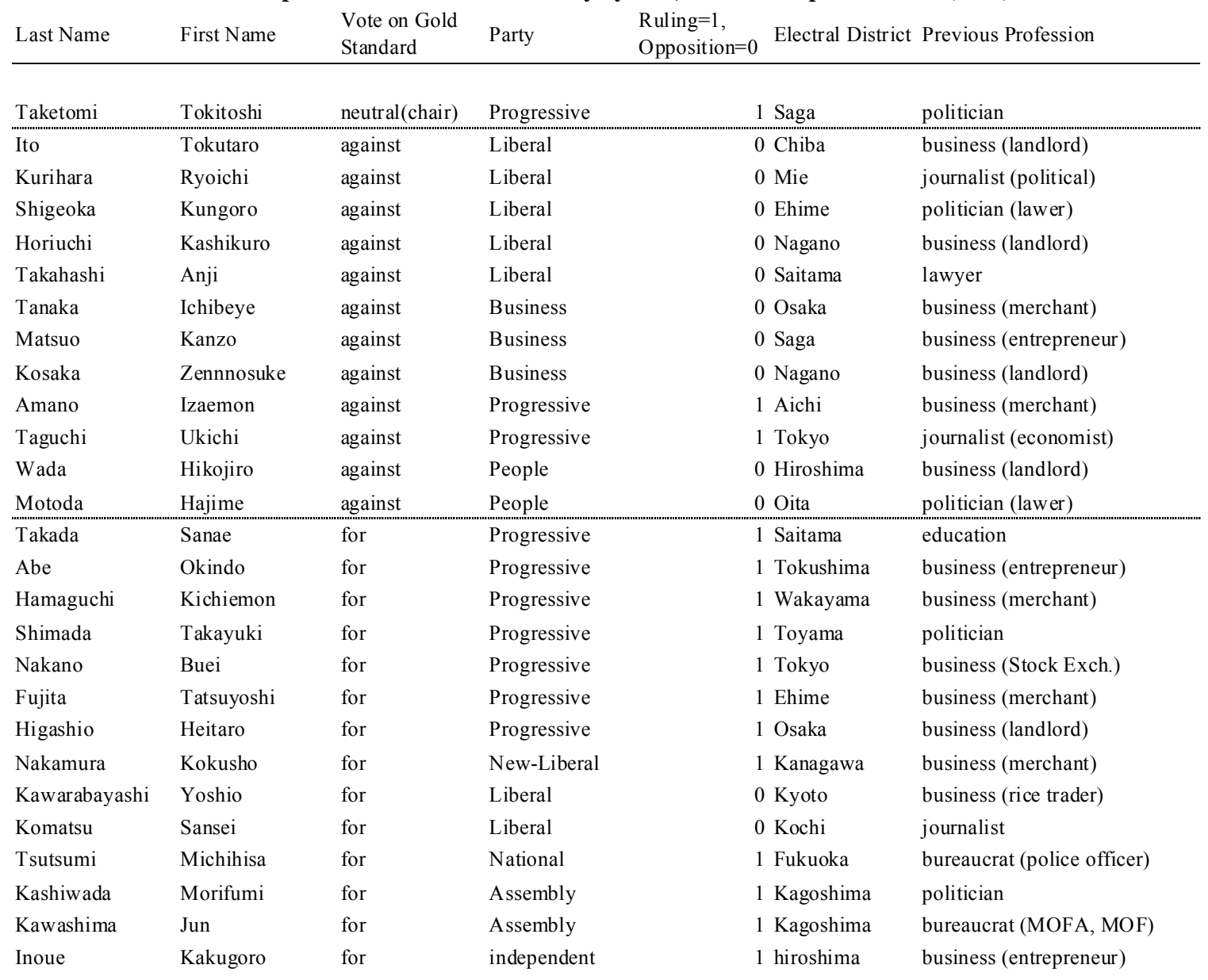

Sources: House of Representatives and House of Peers, Gikai Seido Nanaju Nen Shi

[Seventy Years History of Parliamentary System], 1961. House of Representatives, "Minutes of Committes,"

Official Gazette. Nihon Jinmei Daijiten [Japan Who's Who], Kodansha, 2001. Concise Biographic

Encyclopedia: Japanese Issue, Sanseido, 1976. Ooue, Shiro ed., Meiji Obituary, 1935, reprited by

Tokyo Bijutsu, 1971.

Notes: Private-sector-oriented parties are the Liberal Party, Businessmen's Club, People's Association, Progressive party, and New Liberal Party (which was separated from Liberal Party). Government oriented parties are Assembly Members Club and Nationalist Club. Progressive Party and New Liberal Party were private-sector oriented, but joined a strategic alliance with the ruling government in 1897. 
Table 3 Predicting Voting Behavior in the House Special Committee (1897)

$\begin{array}{lc}\text { Public-sector Profession } & 0.00 \\ & 0.74 \\ & 1.93 * * * \\ & 0.61 \\ \text { Political Party } & -0.19 \\ & -0.24 \\ \text { Silk District } & -0.92 * \\ & 0.48 \\ & \\ \text { Constant } & \\ & \\ & \\ & \\ \text { Pseudo R-squared } & 0.35 \\ \text { Prob }>\text { Chi-squared } & 0.01\end{array}$

Notes: Probit regression where unity equals a vote by a committee member in favor of referring the gold standard legislation the full Diet. *** indicates significant at the 1-percent level. * indicates significant at the 10-percent level. 
Table 4. Selective Japanese Governmnet Bonds traded in the London Market

\begin{tabular}{|c|c|c|c|c|c|c|}
\hline Name of bond issue & $\begin{array}{ll}\text { Date of } & \\
\text { Issuance or } & \text { Coupon } \\
\text { Listing rate }\end{array}$ & & $\begin{array}{l}\text { Issue price } \\
(\text { par }=100)\end{array}$ & $\begin{array}{l}\text { Date of } \\
\text { maturity }\end{array}$ & Total amount (yen) & Means of issuing/listing \\
\hline $9 \%$ Foreign Bond (sterling) & 1870 & 9 & 98 & 1882 & $4,880,000$ & indirect subscription \\
\hline $7 \%$ Foreign Bond (sterling) & 1873 & 7 & 92.5 & 1897 & $11,712,000$ & indirect subscription \\
\hline Consolidated Public Loan Bond & 1896 & 5 & - & 1950 & & $\begin{array}{l}\text { quotation of domestic bond on } \\
\text { London Stock Exchange }\end{array}$ \\
\hline War Loan Bond & 1897 & 5 & 99.9 & 1950 & $43,000,000$ & resale of domestic bond \\
\hline First $4 \%$ Sterling Bond & 1899 & 4 & 90 & 1953 & $97,630,000$ & indirect subscription \\
\hline
\end{tabular}

Sources: Ouchi, Hyoue, Nihon Zaisei Ron: Kousai Hen (Japanese Public Finance: Public Debts), Kaizo-sha, 1932; Ministry of Finance ed., Meiji Taisho Zaisei Shi,vol.11: Kokusai (Financial History of Meiji-Taisho Era, vol.11: Public Debts), 1936. Suzuki (1994). 
Table 5: The Effects of Monetary Standards on Japanese Exports, 1877-1912

\section{Independent Variables}

SilverSilver

GoldGold

PaperPaper

SilverGold

SilverPaper

GoldPaper

GoldSilver

PaperBimetallic

PaperGold

PaperSilver

MFN

Railroad

Population

War

War(-1)

War(-2)

War(-3)

War(-4)

War(-5)

War(-6)

Year Dummies

Observations

*significant at $10 \% ; * *$ significant at $5 \% ; * * *$ significant at $1 \%$
Fixed Effects

PaperSilver Base

$2.482 * * *$

(0.93)

$2.335 * *$

(1.15)

$2.267 * * *$

(0.84)

$2.262 * * *$

(0.79)

0.583

(0.93)

$2.424 * *$

(1.24)

$2.788 * *$

(1.23)

$1.737^{*}$

(1.05)

$2.641 * * *$

(0.68)

0.85

$(0.55)$

0.093

(0.08)

$-0.489 * *$

(0.22)

$-2.345$

(1.65)

0.983

(2.07)

$-1.429$

(2.36)

0.318

(2.39)

$-1.253$

2.34

0.047

(2.07)

$-2.001$

(0.86)

YES

801
Fixed Effects

$\underline{\text { SilverSilver Base }}$

0.242

(1.08)

$-1.388$

(1.07)

$-0.17$

(0.49)

$-1.793 * * *$

(0.67)

0.298

(1.18)

0.587

(1.12)

$-1.899$

(1.25)

$-0.88$

(0.92)

$-4.807 * * *$

(1.07)

0.791

(0.53)

0.0515

(0.08)

$-0.306$

(0.22)

$-2.337$

(1.63)

0.982

(2.05)

$-1.424$

(2.34)

0.982

(2.05)

$-1.231$

(2.32)

0.063

(2.05)

$-1.409$

(1.61)

YES

801 
Figure 1

Japanese Interest Rates on the London Market, May 1873-July 1910 (Basis Points)

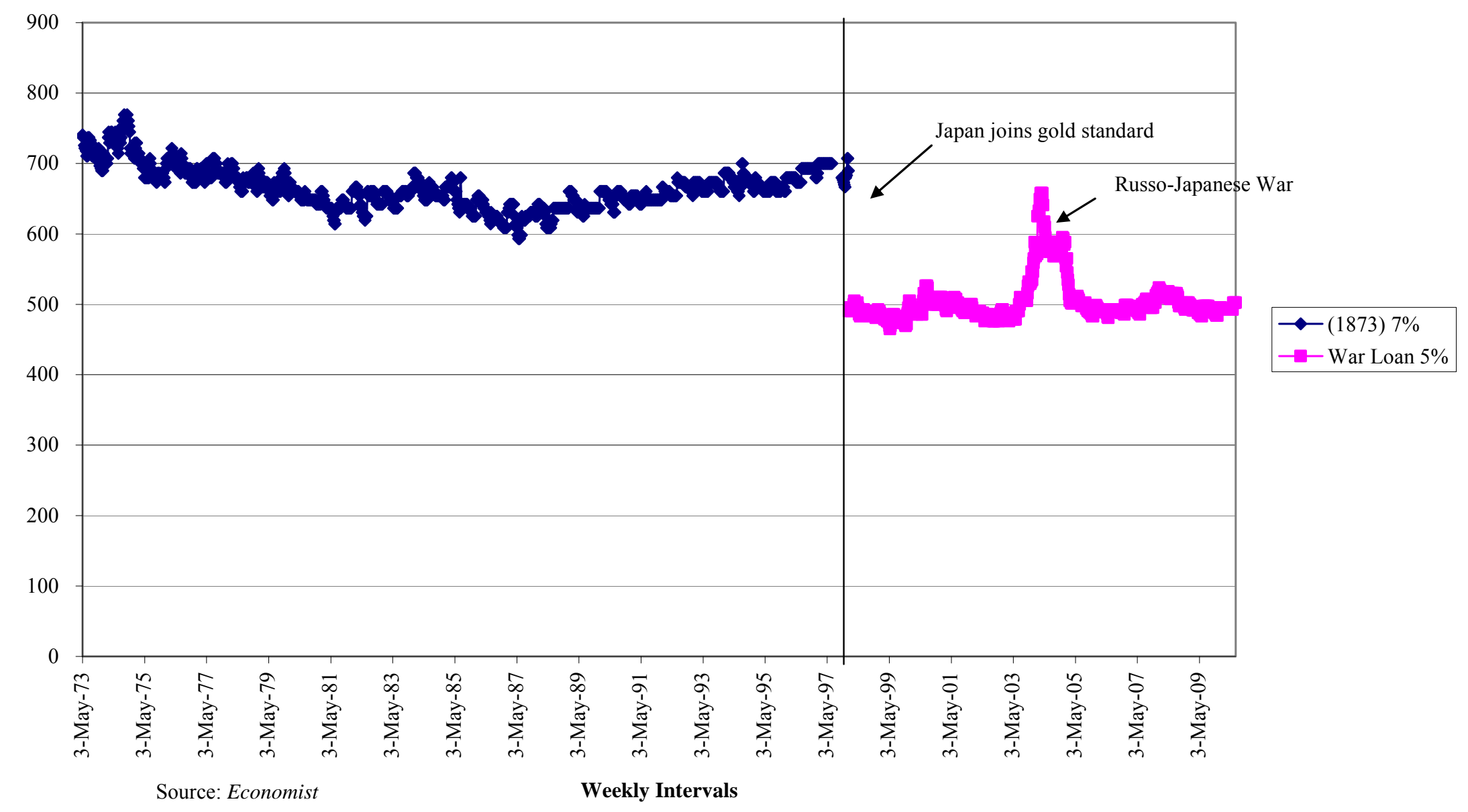


Figure 2

5\% Consolidated Loan in London and Tokyo, 1896-1902

(Basis Points)

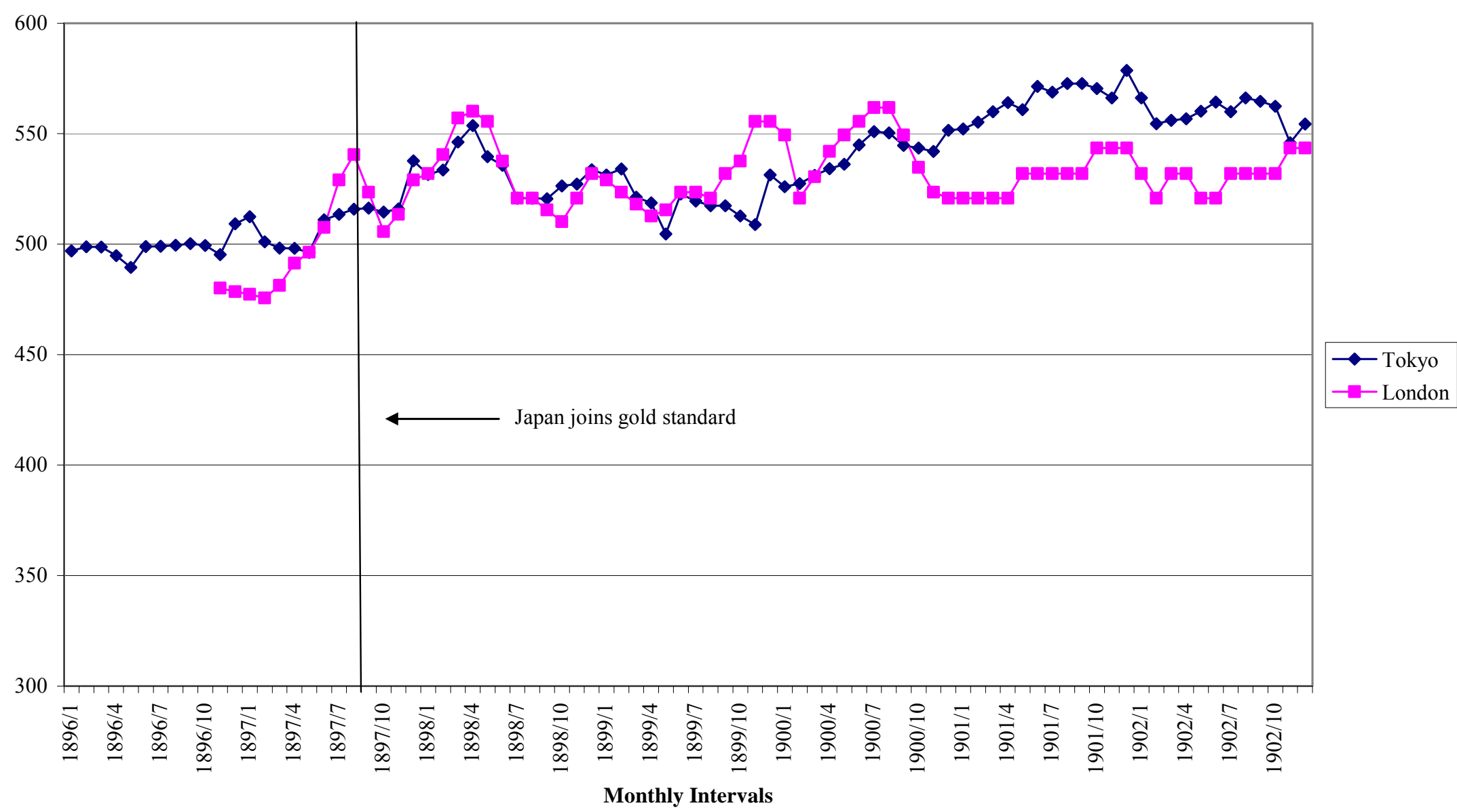


Figure 3

Domestic Japanese Interest Rates, March 1887- June 1910

(Basis Points)

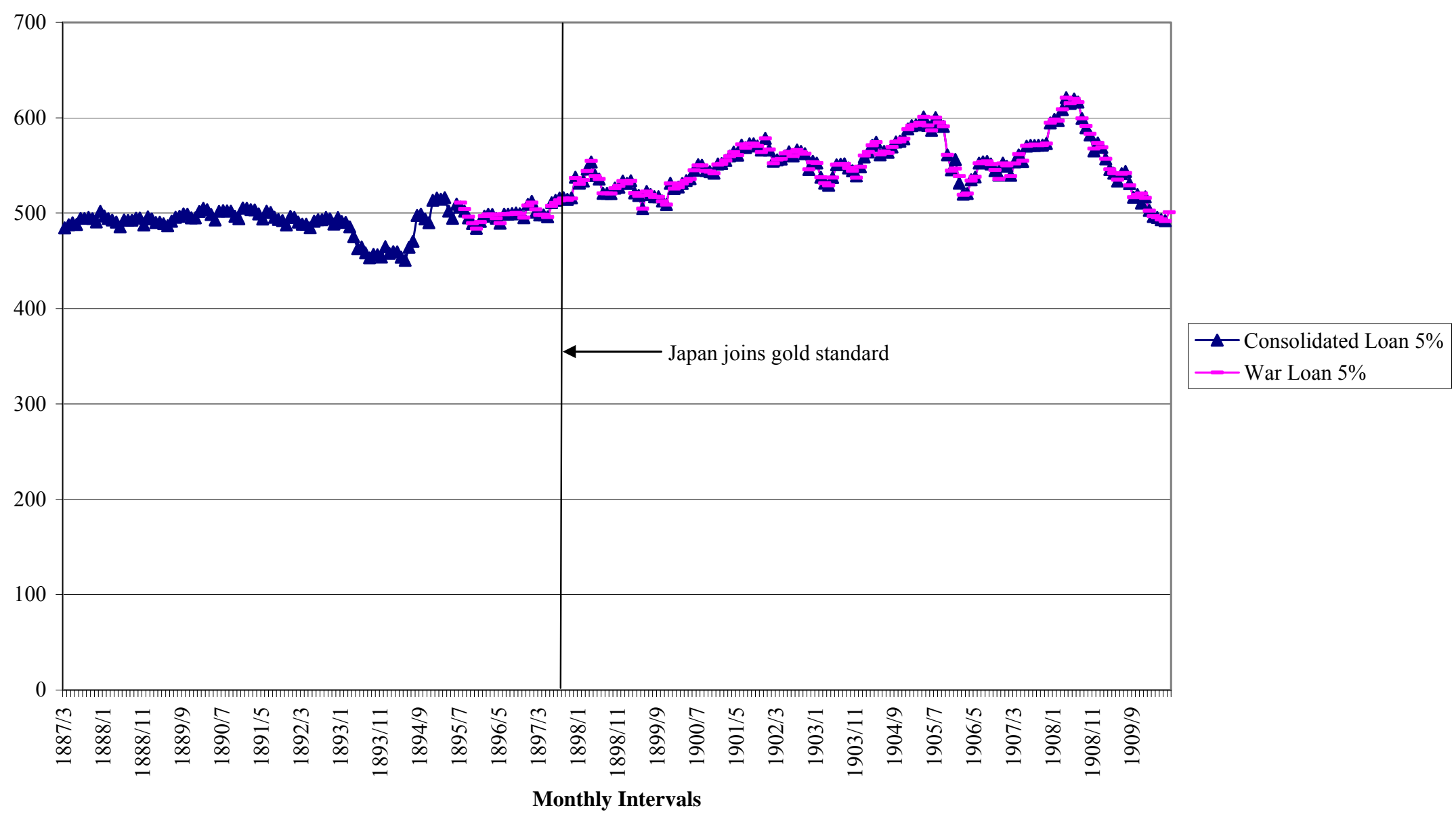


Figure 4

Domestic Japanese Yield Spreads March 1887-June 1910

(Basis Points)

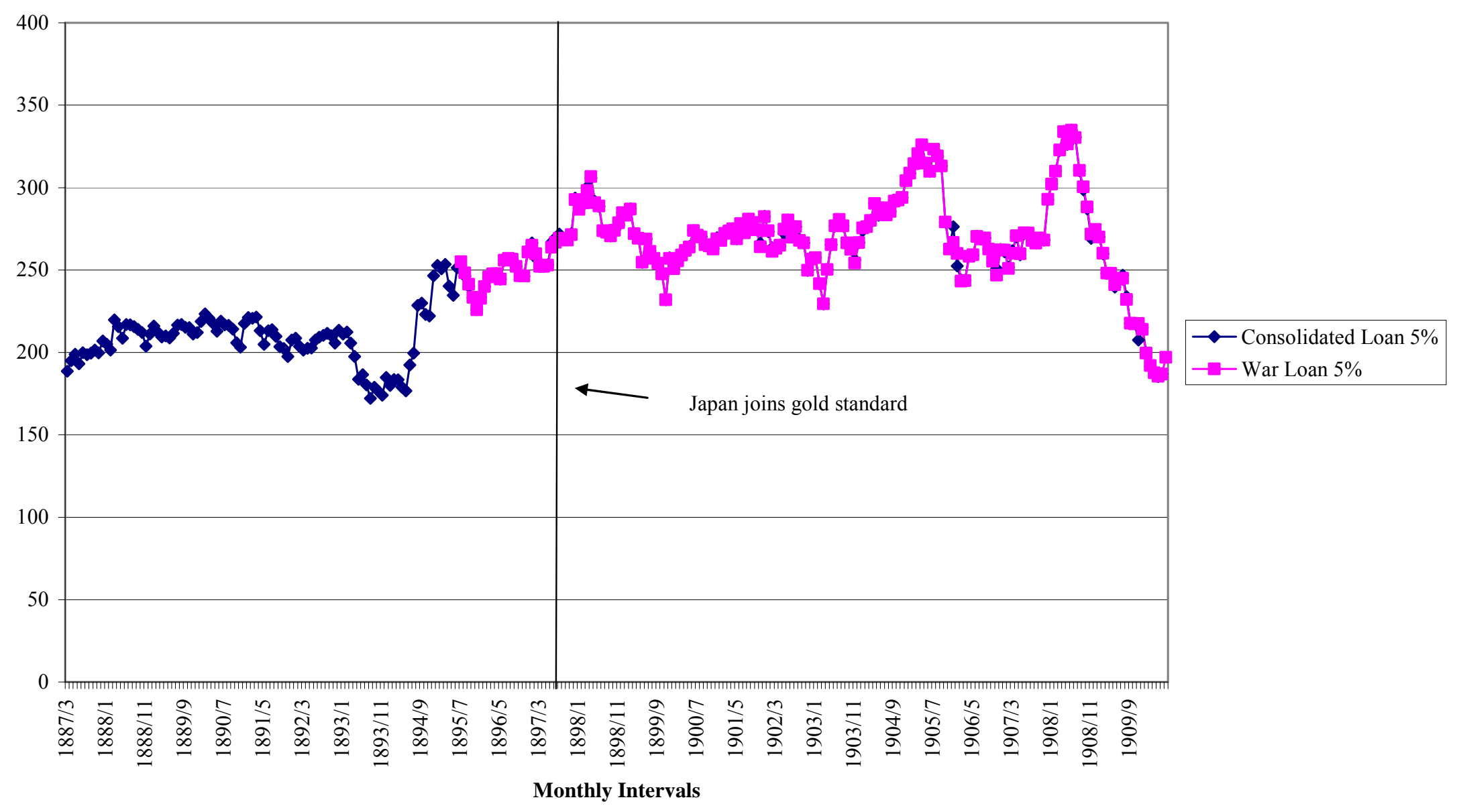


Figure 5

Japanese Stock Market Index, 1895-1899

(January 1895=100)

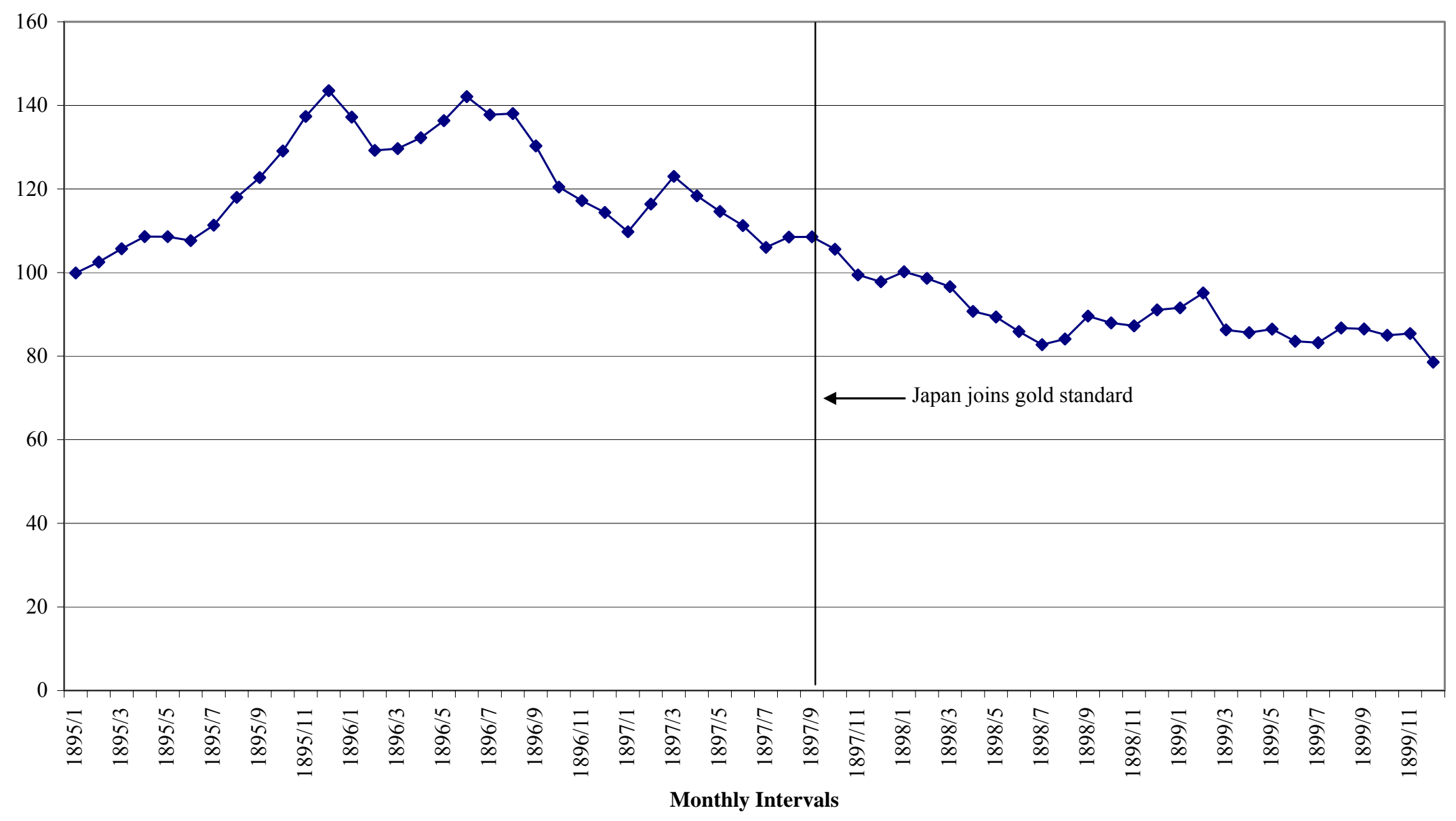


Figure 6

Japanese Stock Market Index, 1895-1899

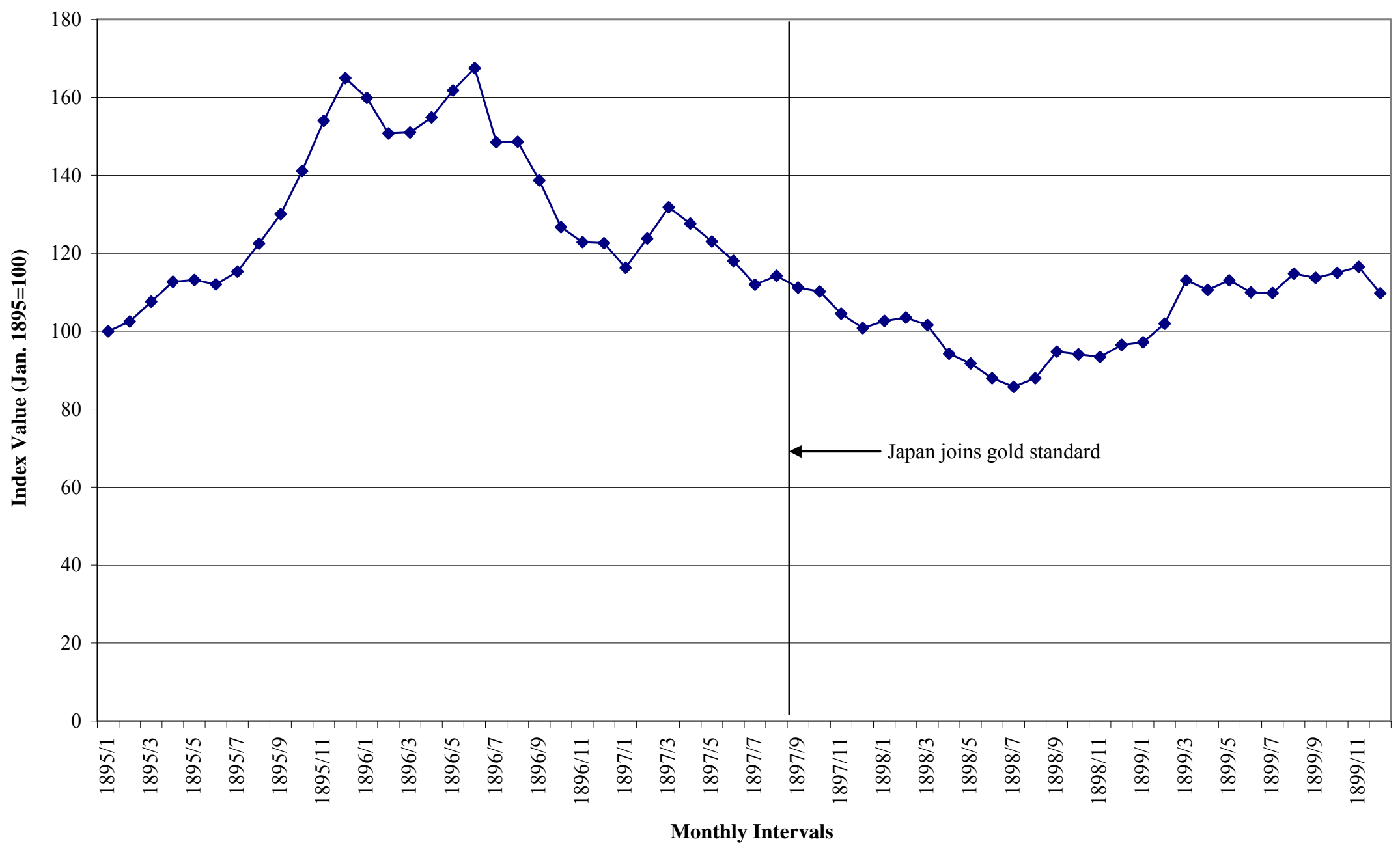


Statistical Appendix: Zivot-Andrews Structural Break Tests, 1887-1910

Panel A: Interest Rates

\begin{tabular}{lc} 
Break Test & $\begin{array}{c}\text { Consolidated Loan } \\
\text { Minimum T-test }\end{array}$ \\
\cline { 2 - 2 } Intercept & -2.665 \\
Trend & -2.933 \\
Intercept and Trend & -3.346 \\
Observations & 275 \\
$*$ significant at $10 \% ; * *$ significant at 5\%;** significant at $1 \%$
\end{tabular}

\begin{tabular}{|c|c|c|}
\hline Break Date & Minimum T-test & Break Date \\
\hline $1897 / 6$ & -2.511 & $1897 / 6$ \\
\hline $1907 / 1$ & -3.356 & $1908 / 3$ \\
\hline $1906 / 12$ & -3.884 & $1907 / 12$ \\
\hline 275 & 175 & 175 \\
\hline
\end{tabular}

\section{Panel A: Yield Spreads}

Break Test
Intercept
Trend
Intercept and Trend
Observations

\begin{tabular}{|c|}
\hline $\begin{array}{c}\text { Consolidated Loan } \\
\text { Minimum T-test }\end{array}$ \\
\hline-3.024 \\
\hline-3.074 \\
\hline-3.199 \\
\hline 275 \\
\hline
\end{tabular}

\begin{tabular}{|c|c|c|}
\hline \multicolumn{3}{|c|}{ War Loan } \\
\hline Break Date & Minimum T-test & Break Date \\
\hline $1894 / 6$ & -2.574 & $1895 / 12$ \\
\hline $1907 / 1$ & -3.685 & $1908 / 3$ \\
\hline $1907 / 1$ & -4.741 & $1907 / 12$ \\
\hline 275 & 175 & 175 \\
\hline
\end{tabular}

